\title{
STUDIES ON THE BIOLOGY OF LIMPETS
}

\section{THE BREEDING OF PATELLA VULGATA L. IN BRITAIN}

\author{
By the late J. H. Orton, F.R.S., A. J. Southward \\ and J. M. Dodd
}

From the Plymouth Laboratory and the Gatty Marine Laboratory, St Andrews

(Plates I and II and Text-figs. I-4)

Some preliminary observations in North Cornwall (Orton, I946) showed that the periods of breeding of the three British species of limpets were different. In order to determine these differences more accurately, and to study the breeding cycle, samples of limpets from six localities in Britain were examined at regular intervals for 5 years. This paper gives the results obtained for the common limpet Patella vulgata, which was present at all the localities sampled and was the most intensively studied of the three species. Later papers will deal with the remaining species and with other aspects of the investigations.

The work fell roughly into two stages. For the first season, 1945-46, it was necessary to determine exactly the distribution of sexes in the various sizegroups at the different stations, since it was known that at Plymouth the small sizes were preponderantly male (Orton, I920, I928) and roughly equal numbers of both sexes are desirable for regular observations on breeding. At the same time the opportunity was taken to re-investigate sex-phenomena which had been noted previously and thought to indicate a change of sex during the life-history (Orton, I920, I928). For the remaining period of study emphasis was placed on determining the exact period of spawning in the various localities, and on possible spawning stimuli.

Although J.H.O. collected most of the samples that were taken personally, as distinct from those collected by other professional or amateur collectors, all three authors have taken part in the field work. J.H.O. was mainly responsible for the examination of the gonad stages, their grouping, and the calculation of the various numerical factors, J.M.D. carried out the histological work and described the arbitrary stages, whilst A. J.S. analysed the breeding cycle and explored the relationship between meteorological factors and spawning. This paper has been prepared by A. J. S. and J. M. D., who are responsible for all opinions expressed herein. 


\section{SAmpling AND Examination of SAMPles}

The regular samples were obtained from the Bay of Nigg, Aberdeen; Pier rocks, St Andrews; Millport, Isle of Cumbrae; Kallow Point, Port St Mary, Isle of Man; Trevone, North Cornwall; and the south side of the breakwater at Plymouth. The collections were usually made at about M.T.L.: the Millport samples, however, were generally taken nearer to H.W.N., while the specimens from Plymouth breakwater were from a ledge half-way between M.T.L. and L.W.N. (see Southward \& Orton, I954, fig. 2, sections C-C and D-D). Additional samples were obtained from other localities in the Isle of Man and near Plymouth during the spawning period to investigate the influence of local factors on spawning.

While many samples were collected personally and examined the same day, a large proportion were sent by post in damp sea-weed, and there was sometimes a delay of up to 4 days between collection and examination of the gonads. The limpets do not seem to have suffered from this treatment: as Eslick (I940) found, they survive well out of water.

The length of the shell was used as an approximate index of size and age. There are no known secondary sexual characters in Patella, and the gonad was therefore examined directly, and its stage of development determined, by cutting away the foot from most of its attachment to the visceral mass and shell, and pushing it over anteriorly, thus disclosing the gonad lying beneath the visceral mass. The sexes could usually be separated clearly by colour (Orton, I928), the male gonad being pinkish white or cream, and the female green or brown (Pl. I), but doubtful cases were examined microscopically. There was no way of distinguishing the sexes of those individuals in the resting phase between spawning and development of the gonad except, in some cases, by microscopic section, and these have been classed simply as the neuter resting stage.

The remaining gonad stages could usually be distinguished as to sex by macroscopic examination. They have been grouped into a series of arbitrary stages, of both development and depletion (spawning), each stage being assigned a roman numeral (Table I). This scheme is based on one put forward in I9Io by a subcommittee of the International Council, for an investigation of herring (cf. Orton, I9I6). It differs from the original scheme in distinguishing between recently spent individuals and those in a resting phase prior to recovery of the gonad. Moreover, in the present scheme all stages represent definite increments in the size of the gonad, and it is therefore possible, in a single index, to define the mean gonad condition of the population.

The samples were first grouped into the arbitrary stages by the use of the criteria given below; the numbers of the sexes in each group, and those neuter, were then recorded. From the data so obtained four variables have been extracted by means of which it is possible to define the breeding state of 
the population sample. One of these is the mean gonad condition, noted above; and the other three are percentages denoting the proportion of the sample in the resting, developing, and spawning condition. The mean gonad condition, or the mean stage of development of the gonad, is determined as follows: the sexes are considered together, since their stage of development is usually identical; the numbers of individuals in each developing gonad stage are multiplied by the number allotted to the stage, the values so obtained being added together. The mean condition of the gonad can then be ascertained by dividing the grand total by the number of individuals in the whole sample.

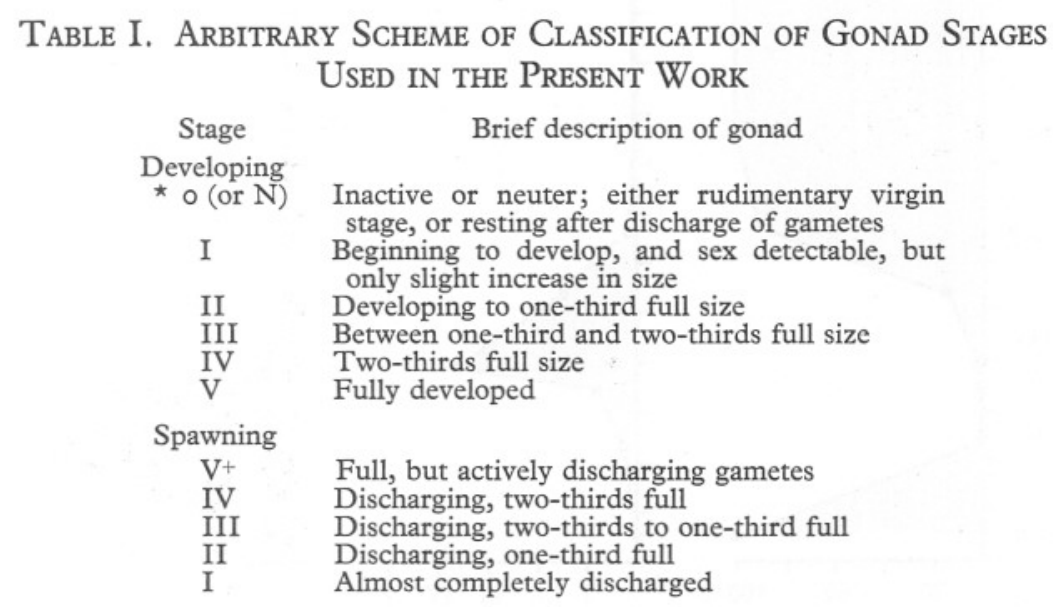

* Virgin and resting stages can be called o and $\mathrm{N}$ respectively, but for purposes of calculation of gonad index, both count as 0 . In the present investigation only the resting stage was concerned in routine work.

An example of a series of samples grouped and treated according to this scheme is given in Text-fig. I. This method of representation brings out clearly the progression of the reproductive cycle, even when, as in Patella, the various stages are prolonged and tend to overlap.

\section{Anatomical Relationships and Histology of the Gonad}

The limpets used for anatomical and histological description of the gonad stages were fixed in Bouin's fluid in sea water and stored in $70 \%$ alcohol. Normal paraffin embedding proved unsatisfactory owing to the size of the mature gonads and the large amounts of reserve material they contained. They were therefore embedded in celloidin which was subsequently impregnated with paraffin wax. Sections were cut at 5 , Io, or $15 \mu$, and stained in either Mallory's triple stain or in Heidenhain's iron-alum haematoxylin followed by eosin or erythrosin Orange- $\mathrm{G}$ as a counterstain. 
The gonad in both sexes lies on the ventral face of the visceral mass betw this and the foot. It is unpaired and slightly displaced to the left (when vier from above). It varies greatly in size and colour throughout the breed. season and its growth causes a good deal of displacement of other organs. I physical reasons it is unable to grow in an anterior direction, consequently anterior margin always lies below the posterior region of the salivary gland
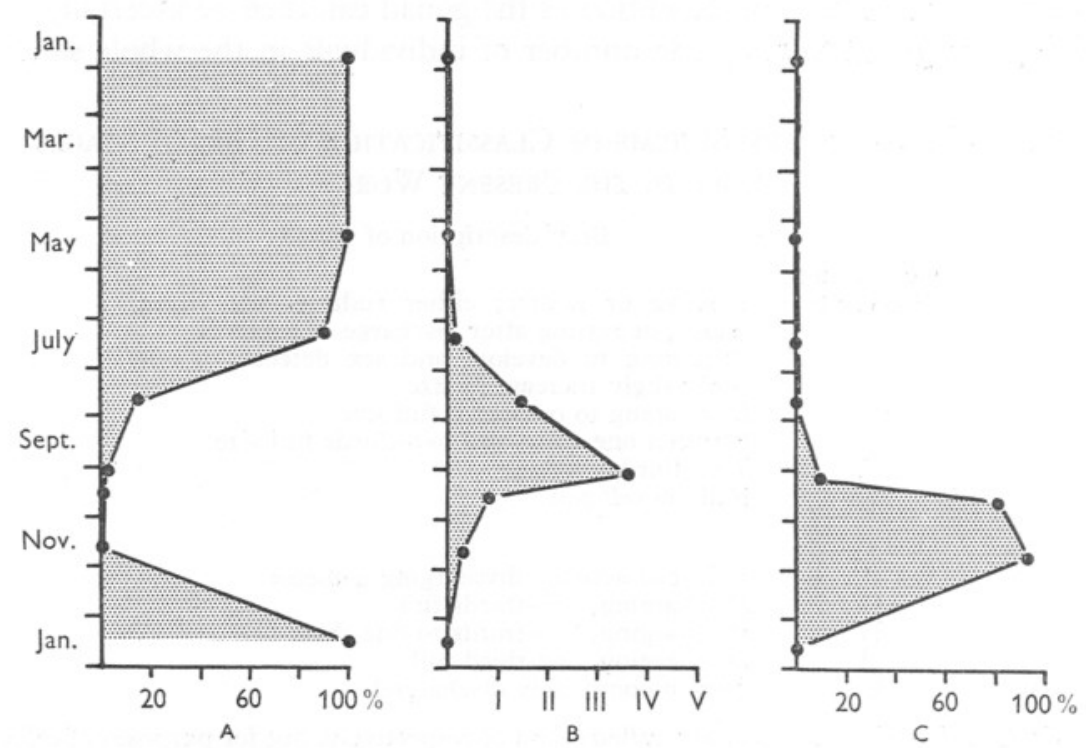

Text-fig. I. Data defining the breeding state of a population (Patella vulgata from Kallow Pt., Port St Mary, Isle of Man, 1946-7; shell length 4.5-5 cm). (A) Percentage with gonad resting (neuter or stage o). (B) Gonad index denoting the mean state of development of the population. (c) Percentage with gonad in the spawning condition.

The outer lateral margin is delimited by a loop of the hind-gut, and the inner margin by the radula. The lateral and posterior regions of the gonad undergo extensive growth, and a striking increase in thickness is noted as ripeness is approached. Text-fig. 2 shows semi-diagrammatically how the gonad increases in extent and thickness throughout its period of growth; the same diagrams also illustrate the reduction in size which occurs as spawning advances. Concomitant changes which occur in the colour of the gonad are associated largely with changes in the proportions of the reserve material. The latter is orange or brown, the pigment being probably identical with the carotenoids found in almost equal amounts in the gonads of both sexes by Goodwin \& Taha (1950) and Goodwin (I950). This pigment becomes dispersed during the development of the gametes. The mature oocytes are coloured green, probably by the 'chromoprotein Y' extracted from female gonads by 
Goodwin \& Taha, while the increasing whiteness of the developing male gonad is related to the sperm content.

These colour changes are described below and some are illustrated in Pl. I. It must be noted that the coloured illustrations differ from Text-fig. 2 in showing the appearance of the gonad as a result of partly freeing the visceral

\begin{tabular}{|c|c|c|c|c|c|c|c|}
\hline Neuter & Stage I & Stage II & Stage III & Stage IV & Stage V \\
\hline & & \\
\hline
\end{tabular}

Text-fig. 2. Patella vulgata: semi-diagrammatic representations of arbitrary stages in the development and depletion of the gonad. Top row: gonad, visceral mass and buccal mass seen from below after removal of the foot. Middle row: longitudinal section of the buccal region and visceral mass passing through the central region of the gonad; plane of section parallel to long axis of body. Bottom row: transverse section of the visceral mass through the widest region of the gonad; plane of section parallel to short axis of body. B.m., buccal mass; G., gut; Go., gonad; R., radula; S.g., salivary glands; V.m., visceral mass.

mass from the foot and turning the latter back as far as it will go while the animal is still in the shell. This was the method used for recognizing the gonad stages in routine analysis; in practised hands it is generally satisfactory. However, as the illustrations in Text-fig. 2 show, a more accurate assessment of gonad state can be made by removing the visceral mass from the foot. 
The Neuter Gonad (Text-fig. 2; P1. II, fig. I)

In limpets of $\mathrm{I} \mathrm{cm}$ and less in shell length the neuter gonad clearly represents the virgin state: in larger specimens which have already spawned it represents the resting spent stage.

The neuter gonad is a discrete reddish brown kidney-shaped structure. It lies on the ventral surface of the visceral mass between this and the foot. The outer and posterior extremities are delimited by a loop of the hind-gut, the anterior margin slightly overlies the salivary glands, and the inner margin lies parallel to the radula at some distance from it.

Microscopic examination of sections shows that the structure of the spent neuter gonad varies with the length of time after spawning at which it is examined. The present description applies to a gonad examined at approximately the middle of the resting period, when it consists of a very thin layer of tissue containing irregular lacunae. In addition, there are sometimes patches of relict ova or sperms, though these are never visible on macroscopic examination and may not be visible in smears. The surface layer is more obvious than in the later stages, and the underlying tissues form a loose reticulum with numerous scattered nuclei. Cell walls are difficult to distinguish and there is no germinal tissue.

\section{Developmental Stages (Text-fig. 2)}

Stage I Gonad (P1. II, figs. 2, 6 and 7)

In the stage I gonad some growth in all dimensions has occurred and sex is recognizable from macroscopic examination. The inner margin of the gonad is contiguous with the radula and the outer and posterior margins almost reach the periphery of the visceral mass.

(a) Female. The female gonad is predominantly brown in colour though tinged with green by the developing eggs. The surface is smooth and delimited by an obvious membrane. The largest eggs are few in number and are separated by nests of developing eggs which can be seen only with a lens.

Microscopic examination of the gonad shows very few medium-sized eggs, most of which are in the central region. The gonad is seen to consist mainly of small oocytes in which vitellogenesis is well advanced, and nests of undifferentiated germ cells. The latter are attached to connective tissue trabeculae

\section{Explanation of Plate I}

Patella vulgata: stages in development and depletion of the gonad showing changes in coloration. In these illustrations the overall colour of the ventral surfaces of the gonads is shown. The foot has been partly removed from the visceral mass and turned forward.

Fig. I. Female; spawning stage I.

Fig. 2. Male; spawning stage I.

Fig. 3. Male; spawning stage I-II.
Fig. 4. Male; spawning stage II.

Fig. 5. Female; developmental stage V.

Fig. 6. Male; spawning stage IV. 
J. MAR. BIol. Ass. U.K., 35 (I)

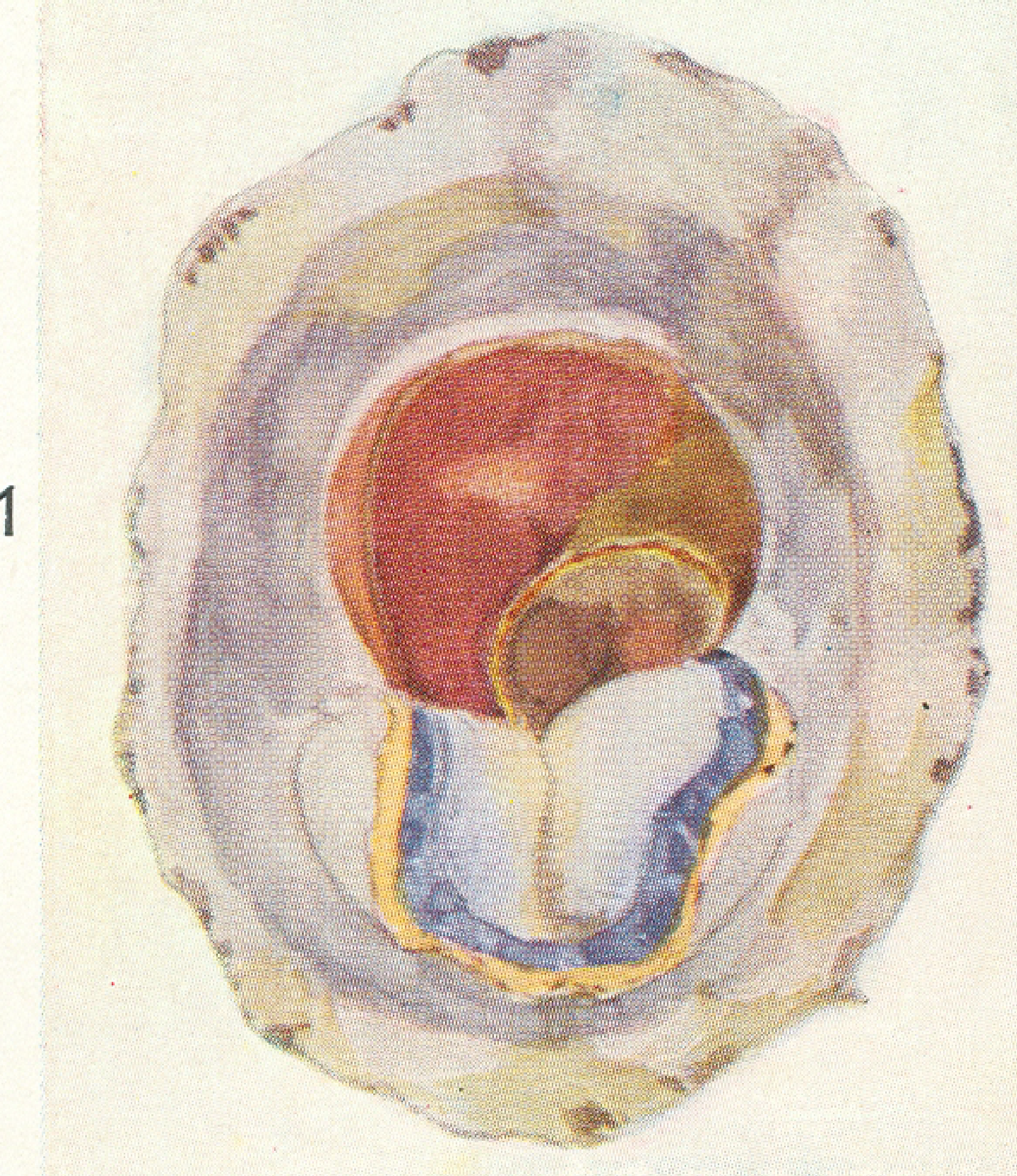

3
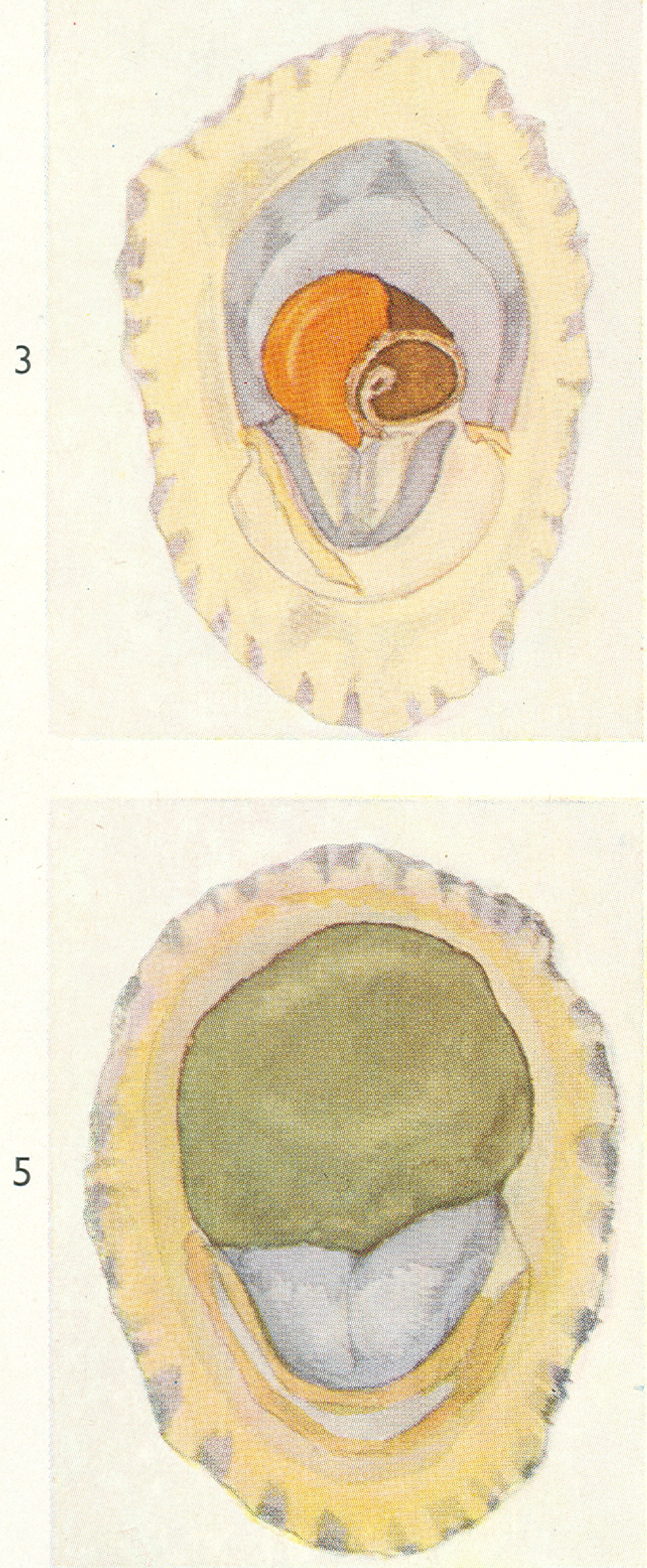

M. Craig pinx.
OrTON, SOUTHWARD AND DODD. PLATE I
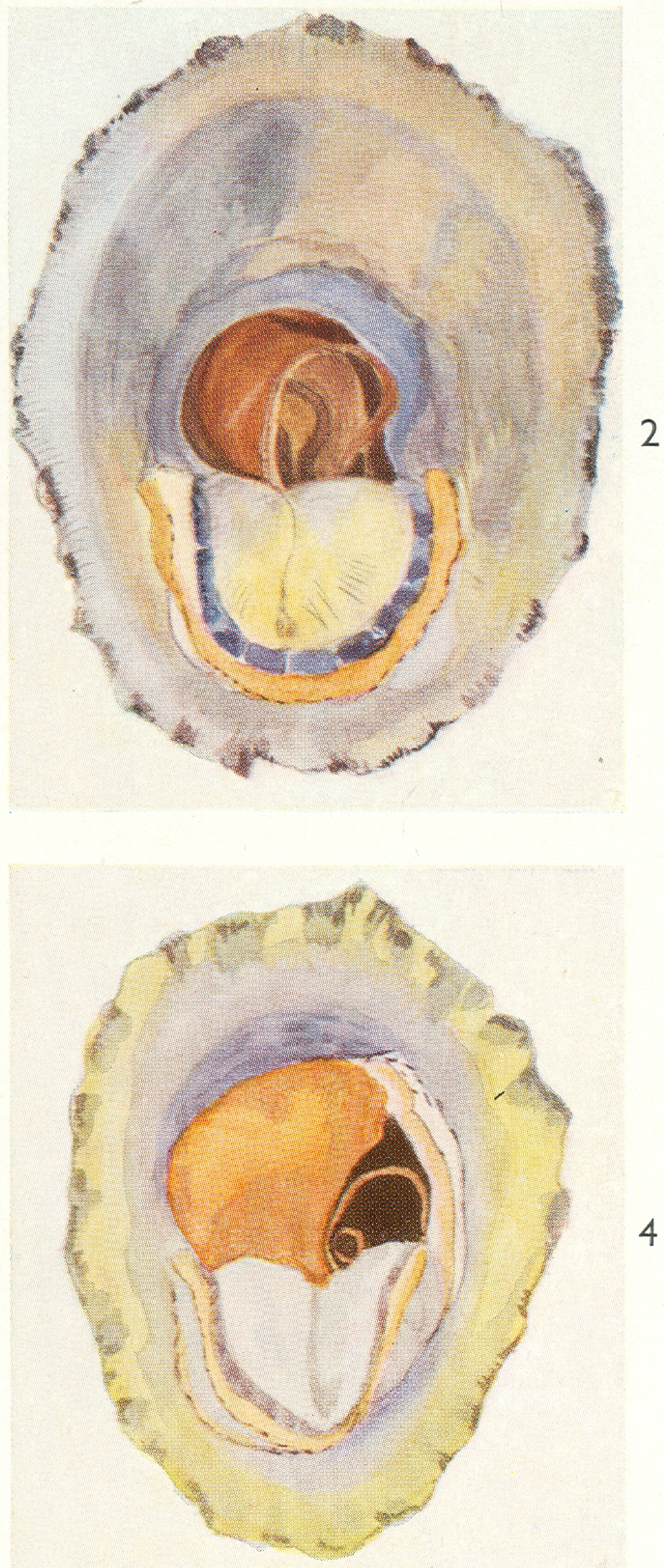

4

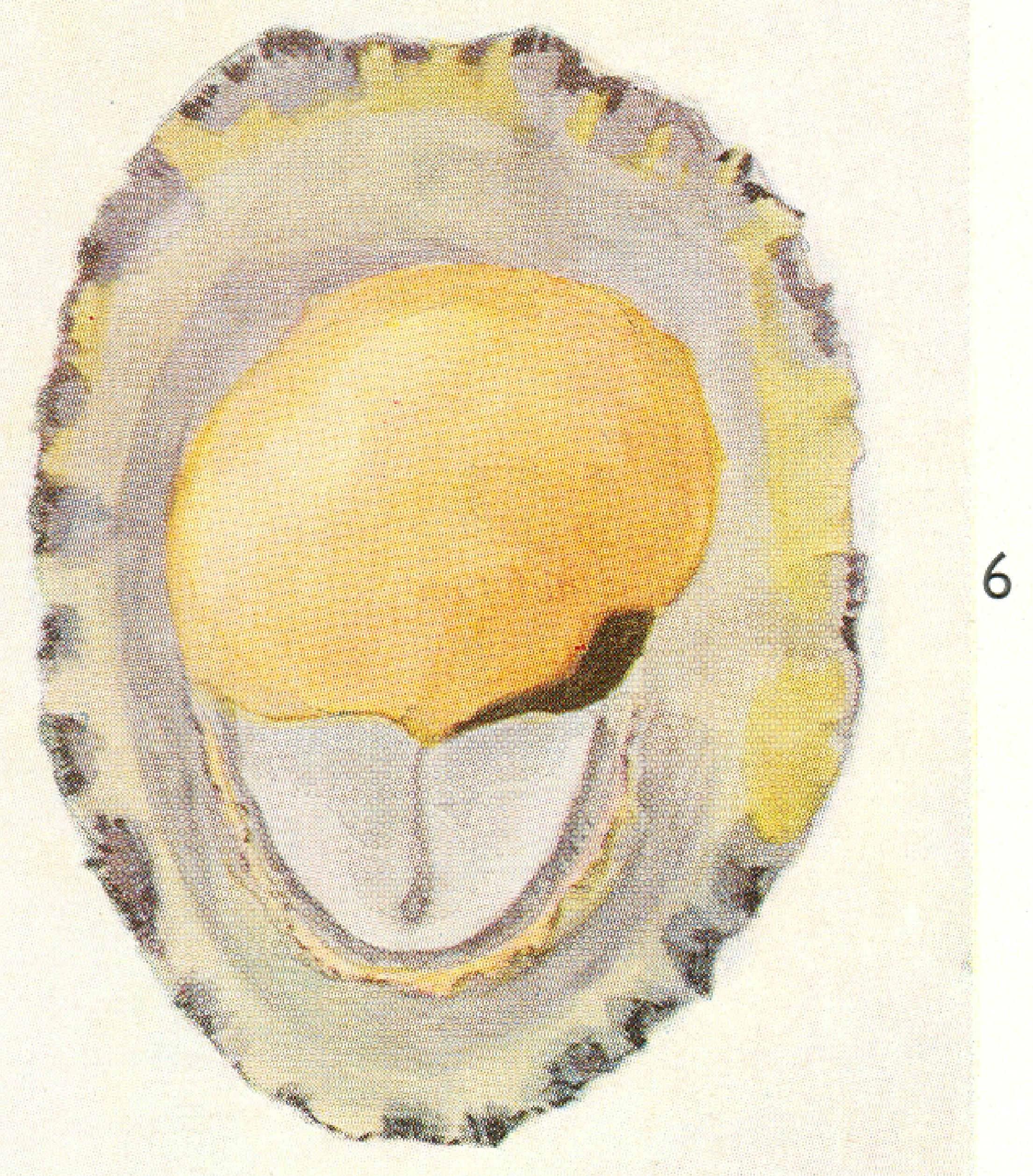

(Facing p. I54) 
which carry the germinal epithelium into the thickness of the gonad. Interstitial tissue is small in quantity.

(b) Male. The male stage I gonad is dark yellowish brown in colour with an obvious membrane. The surface is mottled with white, the white areas representing the cavities of tubules which contain some apparently fully developed spermatozoa.

Microscopic examination shows that the seminiferous tubules of the male gonad are already well developed. The tubules extend inwards from the periphery of the gonad and consist of a connective tissue base which supports thick layers of germinal tissue consisting of spermatogonia, spermatocytes, spermatids and spermatozoa, in that order. The spermatozoa present appear fully developed and lie with their tails projecting into the lumen of the tubules. Spermatogenesis is further advanced in the dorsal regions of the gonad (i.e. those in contact with the visceral mass) as compared with the more ventral.

\section{Stage II Gonad}

By the time this stage has been reached the sexes are easily recognizable by the colour of the gonad. Growth has occurred mainly in posterior and lateral directions, and the gonad now extends over the outer and posterior margins of the visceral mass. A loop of the hind-gut still delimits the outer extremities and the inner margin lies alongside the radula.

(a) Female. The ventral surface of the gonad is smooth and glossy in macroscopic appearance, and the green colour of the eggs is already beginning to mask the brown coloration of the reserve material. There are more large oocytes visible at the surface than in stage I.

Microscopic examination of sections of the stage II gonad shows a great advance in development of the oocytes. Many are now medium to large in size and the 'chorion' layer, which is strongly eosinophil, is a very obvious feature of each egg. Connective tissue trabeculae are well developed and the germinal layer which they support shows representative stages in oogenesis.

(b) Male. The surface of the male stage II gonad shows obvious mottling due to the germinal tubules which reach out to the periphery of the gonad. The peripheral regions of the tubules are brown in colour, whereas the central lumen, full of spermatozoa, is milky white. The arrangement of the tubules gives to the gonad surface an appearance strongly reminiscent of the surface of the mammalian brain, though smooth.

Microscopic examination shows that the proportion of spermatozoa to earlier stages in spermatogenesis is considerably higher than in stage I. Spermatid nuclei are also a prominent feature of the tubule walls. Nuclei which do not stain strongly in Heidenhain's haematoxylin (those of the earliest stages in spermatogenesis), are almost entirely limited to the peripheral regions of the tubules. Active spermatozoa can be obtained from stage II male gonads. 
Stage III Gonad (P1. II, figs. 3, 8)

The stage III gonad shows a considerable increase in thickness when compared with stage II and, also, marked growth of its posterior regions. These have now extended on to the dorsal face of the visceral mass and form a thick extension of its posterior extremity.

(a) Female. The brown colour of the early gonad is now greatly masked by the green eggs. In some specimens the latter are olive-green, whereas in others they are a bright bluish green: several intermediate shades are also encountered. The eggs at the ventral surface of the gonad show marked differences in size.

The stage III gonad is not greatly different in microscopic appearance from the stage II gonad. There are still many small oocytes present, especially on the trabeculae which ramify throughout the gonad. The proportion of large eggs at the surface is slightly higher than in stage II.

(b) Male. The stage III male gonad is yellowish brown mottled with white. The white areas become more extensive as the ripe spermatozoa increase.

Microscopic examination shows a higher proportion of fully developed spermatozoa than in the stage II gonad. The walls of the seminiferous tubules consist mainly of spermatozoa and spermatids, though their peripheral regions contain considerable amounts of reserve material and nests of differentiating germ cells. The difference in ripeness of dorsal and ventral regions of the gonad is now less marked, though the proportion of fully developed spermatozoa in the dorsal region is still somewhat higher.

\section{Stage IV Gonad}

In the stage IV gonad the increase in thickness is yet more marked. This is especially true of the posterior region which now extends well beyond the

\section{Explanation of Plate II}

Patella vulgata: Photomicrographs of sections through male and female gonads in various stages of development and depletion. The plane of section is parallel to the dorso-ventral axis of the gonad. Excepting Figs. I and 6, the photographs show part of the ventral surface of the gonad and the area immediately adjacent to it. Preparations stained with Heidenhain's haematoxylin and eosin.

Fig. I. Neuter gonad. Traces of tubule structure still evident. Note small groups of relict sperms. $\times$ I80.

Fig. 2. L.S. ovary; stage I (developing). $\times 66$.

Fig. 3. L.S. ovary; stage III (developing). $\times 66$.

Fig. 4. L.S. ovary; stage V (developing). $\times 66$. Note 'interstitial' tissue.

Fig. 5. L.S. ovary; stage III (spawning). $\times 66$.

Fig. 6. L.S. seminiferous tubule from stage I male (developing). $\times 300$.

Fig. 7. L.S. testis; stage I (developing). $\times 66$. Note salivary gland tissue in lower righthand corner.

Fig. 8. L.S. testis; stage III (developing). $\times 66$.

Fig. 9. L.S. testis; stage V (developing). $\times 66$.

Fig. Io. L.S. testis; stage III (spawning). $\times 66$. 

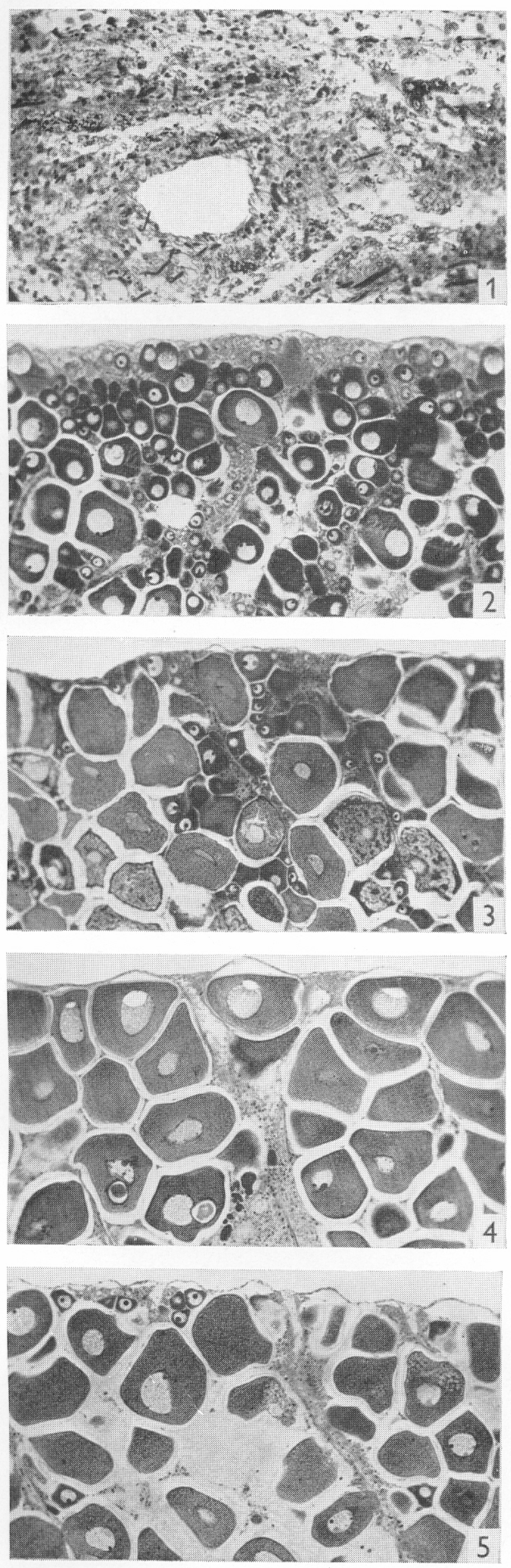
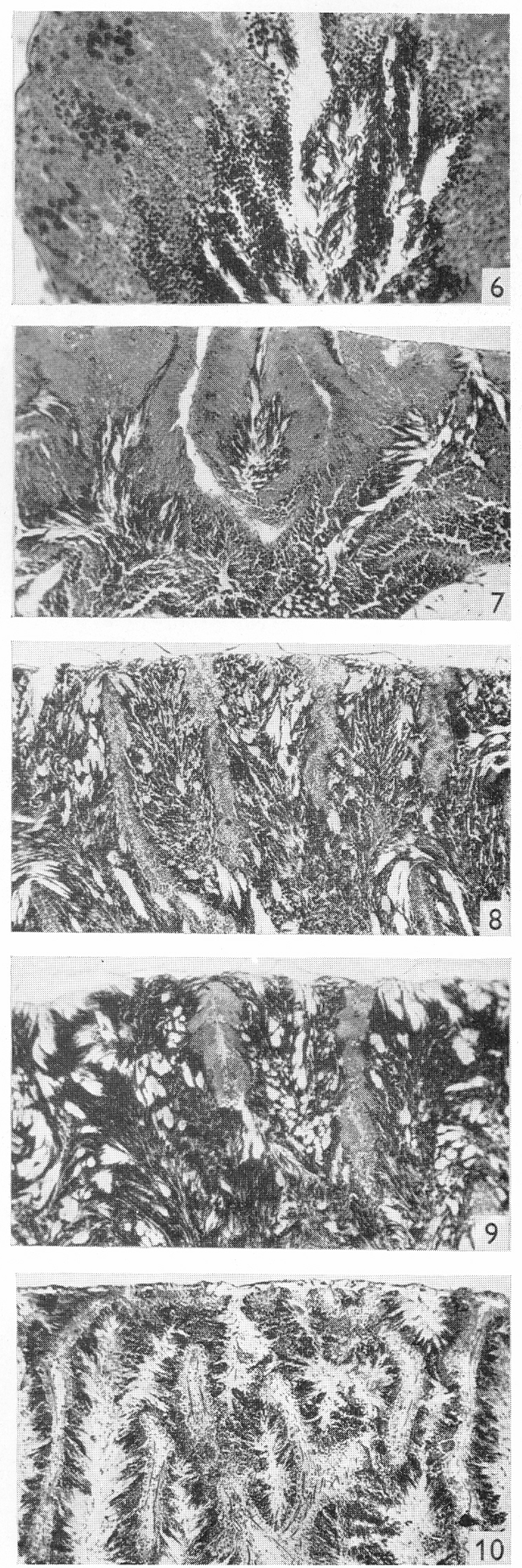

(Facing p. I56) 
limit of the rest of the visceral mass. Some extension of the lateral margins of the gonad has also occurred, and most of the radula has now been displaced on to the lateral face of the visceral mass.

(a) Female. All the eggs visible to the naked eye on the ventral surface of the stage IV gonad are large and uniform. Different individuals show marked differences in colour of the gonad, the commonest colour varieties being bluish green, olive green and olive brown.

Examination of sections shows that the great majority of the surface eggs are now large, though there are a few small oocytes attached to the trabecular tissue. Interstitial tissue is small in amount, being mainly represented by islands of tissue consisting of groups of cells having prominent nuclei, but in which cell boundaries are difficult to identify.

(b) Male. The colour of the stage IV male gonad is predominantly cream, though there are traces of the orange-brown mottling which represents reserve material in the peripheral regions of the seminiferous tubules.

Microscopic examination shows that fully developed spermatozoa are the most prominent constituent, though a few spermatids and earlier stages are present at the periphery of the tubules.

\section{Stage V Gonad (P1. I, fig. 5; P1. II, figs. 4, 9)}

The stage $\mathrm{V}$ gonad is of such a size that it exerts considerable pressure on the tissues which attach the margin of the visceral mass to the foot, and the operation of removing a fully ripe limpet from the rock is often sufficient to tear foot and visceral mass apart. When the visceral mass is partly removed from the foot and turned forward, the entire structure is seen to be overlaid by gonad. To allow for this great increase in gonad volume, the progressive shrinkage in size of the visceral mass, which is noticeable even in the stage III gonad, now reaches a maximum. Although no detailed observations have been made, it appears that feeding either stops or slows down and the gut virtually empties. In this way, since the gut accounts for a considerable part of the volume of the visceral mass, the gonad is allowed to grow in a space of limited volume. The posterior and lateral extension of the gonad which is also a feature of the earlier stages, is maximal in the stage $\mathrm{V}$ gonad.

(a) Female. The stage $\mathrm{V}$ female gonad shows a similar range of coloration to stage IV, from which it differs mainly in size. The surface eggs are large and uniform in size and appear loose and ready for shedding.

Microscopic examination of sections shows that the gonad is an almost uniform mass of large eggs in which only traces of the original trabeculae remain and there are very few developmental stages. Each egg is invested by a very thin 'chorion' which, in most preparations, has become separated from the surface of the egg in consequence of the histological procedures employed. There are evident islands of interstitial tissue consisting of masses of small 
cells with densely staining nuclei. These islands are characteristic of all the later developmental stages: their function is unknown.

(b) Male. The overall colour is whitish cream, the brown mottling being largely masked. Surface patches are commonly found which are white in colour and these are believed to represent areas in which spermatozoa are being liberated prior to shedding.

Microscopic examination shows an almost uniform mass consisting mainly of fully developed spermatozoa. The majority of these are attached to the germinal epithelium. A considerable proportion of spermatids is still present, though earlier developmental stages are uncommon. The peripheral areas of the gonad frequently show irregular lacunae.

\section{Spawning Stages (Pl. I; Pl. II, figs. 5, I0)}

Gonads undergoing regression are subdivided in the same manner as are the progressive developmental stages. Thus a gonad in which spawning has occurred to the extent that it is morphologically similar to developmental stage III is classified as spawning stage III.

Spawning gonads are difficult to distinguish from developing gonads by any morphological criteria. Early spawning stages in females can be distinguished to some extent by the appearance of the surface eggs: as spawning advances they appear much more loosely packed than in the corresponding developmental stages and, in addition, they are more uniformly large. They appear more rounded and seem to be detached from the substratum of the gonad as though ready for shedding. Corresponding stages in development and regression are slightly different in colour, the proportion of the brown non-germinal tissue being higher in the latter. Microscopic examination of sections shows more striking differences, though this method of study would be less practicable for the large-scale investigation of the breeding cycle. The uniformity of the eggs and the pronounced gaps between them, occupied by a loose chromophobe connective tissue, are highly characteristic features (Pl. II, fig. 5). However, considerable numbers of small oocytes are often present in the spawning gonad, since spawning frequently alternates with subsidiary bursts of development. In spawning males, the gonad frequently shows white patches in which the tubules appear to have broken down and, furthermore, the colour of the brown non-germinal tissue changes from orange-brown to a darker brown and becomes progressively greater in relative amount as spawning advances. Sections of male gonads in which spawning is far advanced have a highly characteristic appearance. The main constituent is the chromophobe non-germinal tissue: fully developed spermatozoa are few in number and limited to the free edges of the tubules. Earlier stages in spermatogenesis are practically non-existent.

Thus the criteria that exist for separating spawning individuals from those 
which are developing are undoubtedly somewhat subjective and difficult to distinguish and describe: they become recognizable only as a result of considerable experience in examining gonads throughout the breeding season.
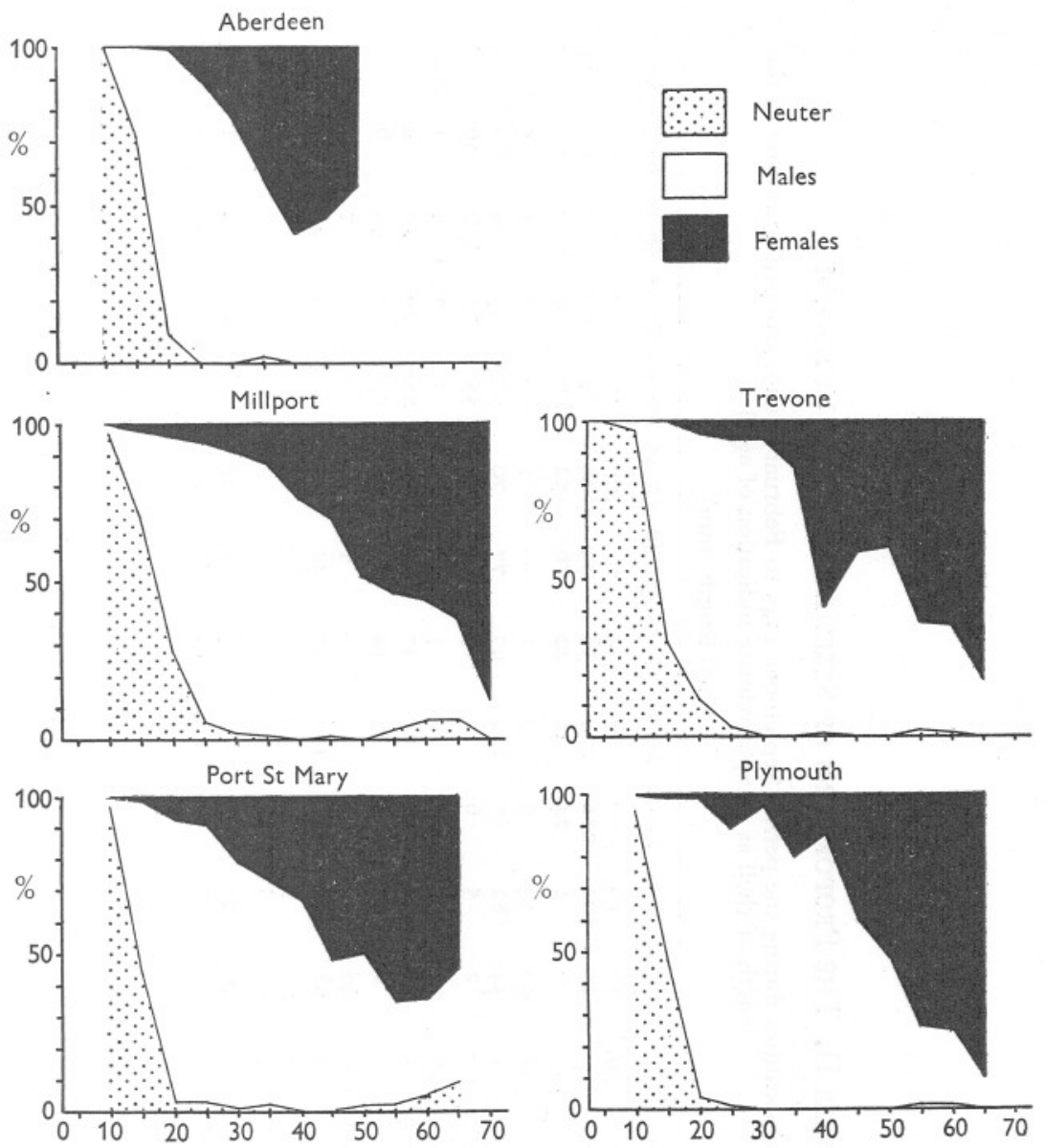

Text-fig. 3. Patella vulgata: the proportions of sexes at different shell lengths (5 $\mathrm{mm}$ groups) in samples from several localities, I945-6.

\section{SEX Proportions}

Approximately Iooo individuals were examined from each of the localities Aberdeen, Millport, Port St Mary, Trevone and Plymouth, between September 1945 and February I946. As far as possible about Ioo specimens were examined in each $5 \mathrm{~mm}$ size-group. The actual numbers of males, females, and neuter individuals in each size-group is given in Table II, while their distribution as a percentage of the total number of specimens examined is 
Table II. The Proportions of Sexes in PATELLA VUlGata

(Samples from several localities during the period September 1945 to February 1946, grouped according to the length of shell as an approximate indication of age.)

Shell length (mm)

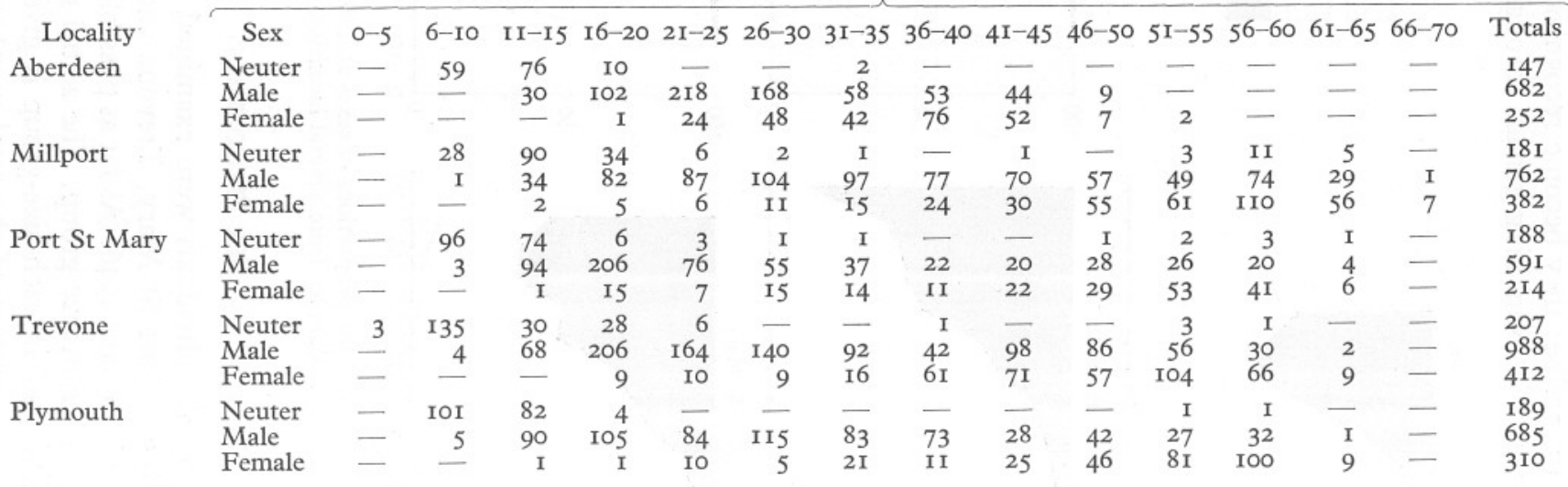


shown in Text-fig. 3. As has been known for some time (Orton, I920, I928) the smaller sizes of limpet in which sex can be determined are almost entirely male, while the larger sizes are preponderantly female. In the range up to Io $\mathrm{mm}$ shell length practically all specimens examined in the present study were neuter, but between $\mathrm{I} 6$ and $25 \mathrm{~mm}$ at all localities there were at least $90 \%$ males. The two sexes were approximately equal in number in specimens having a shell length around $40 \mathrm{~mm}$, while $60-70 \%$ of those specimens having a shell length of $60 \mathrm{~mm}$ were female (such large specimens were not found in the Aberdeen samples). In limpets having a shell in excess of $60 \mathrm{~mm}$ even higher proportions of females were sometimes found (Millport, Trevone, Plymouth), but this may have been due to the small numbers examined.

These changes in sex proportions with length can be explained in two ways. If one assumes that the rates of growth and development of males and females are similar, and this is certainly true for the gonad, it can be suggested that almost all individuals start their breeding life as males, but that later in life a large proportion of them become female. On the other hand, if one assumes that the rate of growth and development may differ markedly in the two sexes, the preponderance of females in the larger size-groups can be explained by differential mortality, more than $90 \%$ of the males dying before they reach a shell length of $60 \mathrm{~mm}$.

Of these explanations, that of change of sex is the simpler and more acceptable, since the phenomenon occurs in many other molluscs. Sexreversal in such an animal does not involve major anatomical changes since there are no secondary sexual characters. The long resting phase of the gonad, when the sexes are not discernible, and the general similarity of the breeding cycle in male and female makes sex change very difficult to detect. No direct evidence is yet available, but we will return to the problem when considering the other species of Patella which show very different sex proportions.

\section{The BReEding Cycle}

The preliminary observations showed that collection of individuals from 30 to $60 \mathrm{~mm}$ shell length would provide roughly equal numbers of males and females. Regular samples of these sizes were obtained from each locality, at monthly intervals during the relatively inactive periods and more frequently about the time of spawning.

At first, samples of Ioo were examined, but it was later found to be possible to reduce this number by half without affecting the results. From Millport, Port St Mary, Trevone and Plymouth, sampling was maintained from the spring of I 946 to the end of I949. The Aberdeen samples were insufficient in I946 and I947, and the series was discontinued in 1949, being replaced by the St Andrews samples, not begun until late in 1947. The results from these samples are given in Tables IV-IX (Appendix) as numbers of individuals 
found in each gonad stage in the separate sexes, and in the neuter or resting stage. The four variables used to define the breeding state of the population (p. 4) have been extracted from these tables, and are shown in Text-fig. 4.

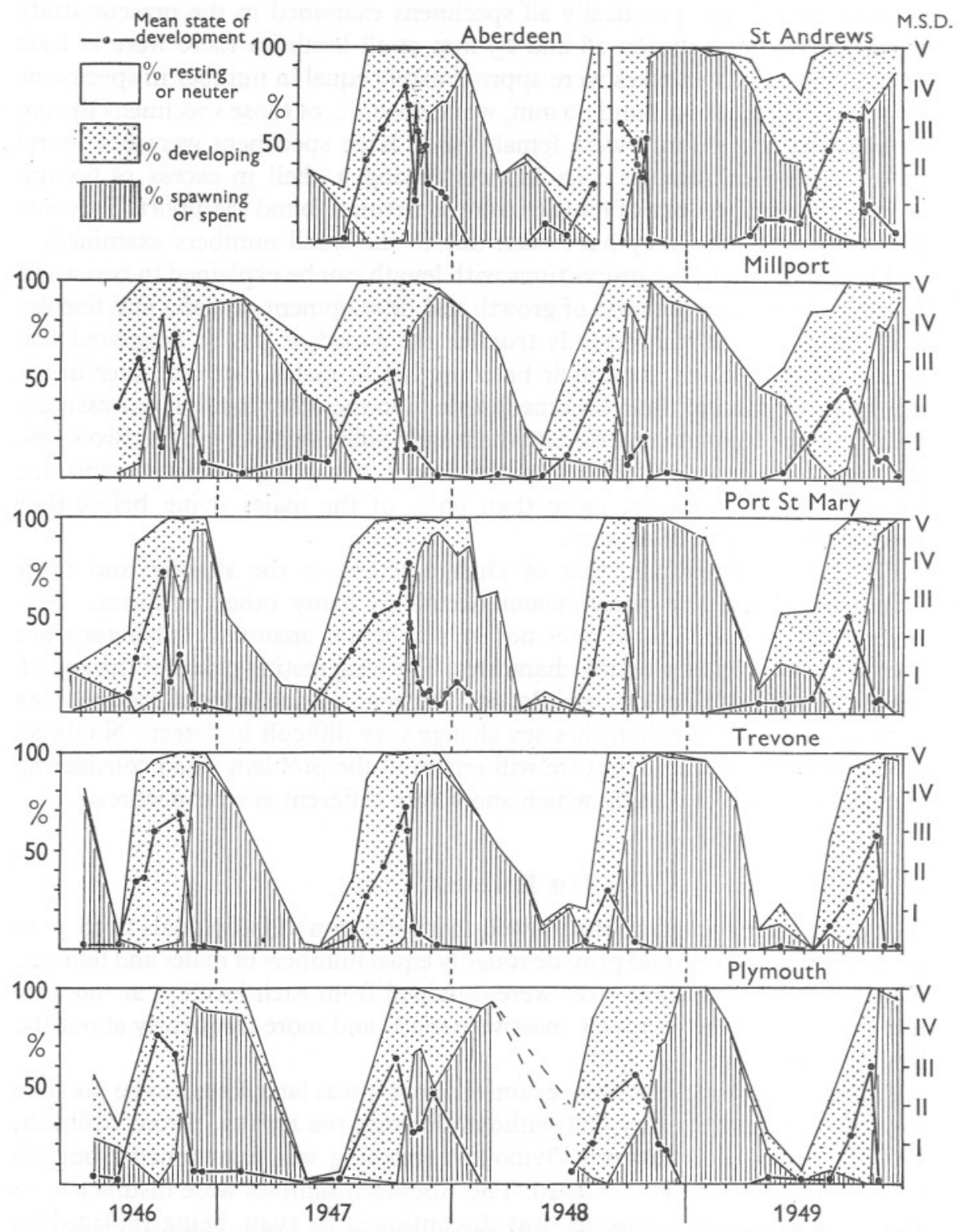

Text-fig. 4. Patella vulgata: the breeding cycle of samples from several localities, I946-9, showing the percentages with gonad resting, developing, and spawning. The thick line gives the mean state of development of the gonad (ordinates on right side). 
From the Tables and Text-fig. 4 it can be seen that $P$. vulgata has a long resting phase: during the spring and early summer the animal is effectively neuter. This phase must last up to 9 months in some individuals, and for over 3 months in $50 \%$ of the population, except at St Andrews, where it is rather short. The resting phase is followed by a much shorter period of development from June to October, not usually more than 3-4 months, during which the gonad increases steadily in size. There may be a further period of up to I month during which little change takes place in the samples. At this stage the gonad is apparently fully mature, and a high proportion of viable larvae may be obtained by artificial fertilization. Some time between the beginning of September and the end of October, according to year and locality, a comparatively rapid change from the developing to the spawning condition takes place. Finally, the proportion of spawning and spent individuals declines slowly and regularly between December and June, as more and more pass into the resting condition.

This cycle is subject to some variation from year to year and variation is also shown between the different localities. Only at the more northerly stations (Aberdeen, St Andrews, Millport; cf. Text-fig. 4) did the spawning and developing phases overlap: in the other localities a higher proportion of the limpets passed into the resting phase together, while the periods of development and spawning were shorter. This suggests that temperature may influence the resting period, and that the emptying of the gonad, and its change to the resting phase is speeded up by the warmer conditions in the south. Temperature differences may also explain the fact that gonad development starts earlier in the more northern localities, in which a longer development period may be necessary because of the lower environmental temperatures. However, temperature differences can hardly account for the variations in the exact time of onset of spawning at the different stations, since, of the years studied, only 1949 and 1952 showed a significant difference between the northerly and southerly localities in this respect.

\section{SPAWNING}

The dates between which spawning started and those on which most (at least $90 \%$ ) of the limpets in the samples were in the spawning condition are given in Table III. This table includes information for some other stations, in addition to those regularly sampled, and for 1952, when only the spawning period was studied. More precise information for the regular samples will be found in the Appendix Tables IV-IX, while Text-fig. 4 shows diagrammatically the onset of spawning.

In some years, notably I947 and I948, spawning seems to have started practically simultaneously at all stations towards the end of October. At Plymouth (both stations) spawning again began in October in 1946, I949 and 
Table III. The Spawning Period of Patella vUlgata at Several British Localities in i947-49 and 1952

\begin{tabular}{|c|c|c|c|c|c|c|c|c|c|c|}
\hline & \multicolumn{2}{|c|}{1946} & \multicolumn{2}{|c|}{ I947 } & \multicolumn{2}{|c|}{ I948 } & \multicolumn{2}{|c|}{1949} & \multicolumn{2}{|c|}{1952} \\
\hline & $\begin{array}{l}\text { Dates } \\
\text { between } \\
\text { which } \\
\text { spawning } \\
\text { began }\end{array}$ & $\begin{array}{c}\text { Date at } \\
\text { which } 90 \% \\
\text { of sample } \\
\text { were } \\
\text { spawning }\end{array}$ & $\begin{array}{l}\text { Dates } \\
\text { between } \\
\text { which } \\
\text { spawning } \\
\text { began }\end{array}$ & $\begin{array}{c}\text { Date at } \\
\text { which } 90 \% \\
\text { of sample } \\
\text { were } \\
\text { spawning }\end{array}$ & $\begin{array}{l}\text { Dates } \\
\text { between } \\
\text { which } \\
\text { spawning } \\
\text { began }\end{array}$ & $\begin{array}{c}\text { Date at } \\
\text { which } 90 \% \\
\text { of sample } \\
\text { were } \\
\text { spawning }\end{array}$ & $\begin{array}{l}\text { Dates } \\
\text { between } \\
\text { which } \\
\text { spawning } \\
\text { began }\end{array}$ & $\begin{array}{c}\text { Date at } \\
\text { which } 90 \% \\
\text { of sample } \\
\text { were } \\
\text { spawning }\end{array}$ & $\begin{array}{l}\text { Dates } \\
\text { between } \\
\text { which } \\
\text { spawning } \\
\text { began }\end{array}$ & $\begin{array}{c}\text { Date at } \\
\text { which } 90 \% \\
\text { of sample } \\
\text { were } \\
\text { spawning }\end{array}$ \\
\hline Aberdeen & - & - & $\begin{array}{l}9 \text { Sept. to } \\
\text { I7 Oct. }\end{array}$ & $\begin{array}{l}\text { I9 Jan. } \\
\text { I948 }\end{array}$ & $\begin{array}{l}7 \text { Sept. to } \\
\text { ro Oct. }\end{array}$ & 6 Dec. & - & - & - & - \\
\hline St Andrews & - & - & $\begin{array}{l}\text { Before } \\
3 \text { Nov. }\end{array}$ & 5 Nov. & $\begin{array}{l}\text { I7 Sep. to } \\
\text { I8 Oct. }\end{array}$ & 2 Nov. & $\begin{array}{l}22 \text { Sept. to } \\
30 \text { Sept. }\end{array}$ & $\begin{array}{c}\text { Not in } \\
1949\end{array}$ & $\begin{array}{l}21 \text { to } \\
27 \text { Sept. }\end{array}$ & 4 Oct. \\
\hline Millport & - & - & $\begin{array}{l}\text { I Oct. to } \\
\text { I8 Oct. }\end{array}$ & 9 Dec. & $\begin{array}{l}30 \text { Sept. to } \\
2 \text { Nov. }\end{array}$ & 2 Nov. & $\begin{array}{l}\text { Io Aug. to } \\
3 \text { Sept. }\end{array}$ & 24 Nov. & $\begin{array}{l}\text { Before } \\
2 \text { Oct. }\end{array}$ & $\begin{array}{l}\text { Before } \\
2 \text { Oct. }\end{array}$ \\
\hline $\begin{array}{l}\text { Port St Mary, Isle } \\
\text { of Man }\end{array}$ & $\begin{array}{l}\text { 2I Aug. to } \\
3 \text { Sept. }\end{array}$ & 25 Nov. & $\begin{array}{l}6 \text { Oct. to } \\
22 \text { Oct. }\end{array}$ & 20 Nov. & $\begin{array}{l}24 \text { Sept. to } \\
\text { I3 Oct. }\end{array}$ & I3 Oct. & $\begin{array}{l}5 \text { Sept. to } \\
\text { 17 Oct. }\end{array}$ & 23 Oct. & $\begin{array}{l}\text { Before } \\
3 \text { Oct. }\end{array}$ & 24 Oct. \\
\hline $\begin{array}{l}\text { Other places on east } \\
\text { side of Isle of Man }\end{array}$ & - & - & $\begin{array}{l}\text { I Oct. to } \\
5 \text { Oct. }\end{array}$ & 2 I Nov. & $\begin{array}{l}24 \text { Sept. to } \\
25 \text { Sept. }\end{array}$ & 25 Oct. & $\begin{array}{l}5 \text { Sept. to } \\
20 \text { Oct. }\end{array}$ & - & - & 一 \\
\hline $\begin{array}{l}\text { West side of Isle } \\
\text { of Man }\end{array}$ & 一 & - & $\begin{array}{l}\text { I5 Oct. to } \\
28 \text { Oct. }\end{array}$ & 一 & $\begin{array}{l}6 \text { Sept. to } \\
22 \text { Oct. }\end{array}$ & 22 Oct. & - & - & - & - \\
\hline Trevone & $\begin{array}{l}24 \text { Sept. to } \\
2 \text { Nov. }\end{array}$ & 25 Nov. & $\begin{array}{l}\text { I7 Sept. to } \\
\text { I I Oct. }\end{array}$ & I4 Nov. & $\begin{array}{l}30 \text { Aug. to } \\
\text { I3 Oct. }\end{array}$ & I3 Oct. & $\begin{array}{l}\text { Io Sept. to } \\
\text { I9 Sept. }\end{array}$ & 4 Nov. & $\begin{array}{l}\text { Before } \\
3 \text { Oct. }\end{array}$ & $\begin{array}{l}\text { Before } \\
3 \text { Oct. }\end{array}$ \\
\hline Plymouth Breakwater & $\begin{array}{l}\text { I Oct. to } \\
28 \text { Oct. }\end{array}$ & 27 Nov. & $\begin{array}{l}6 \text { Oct. to } \\
3 \text { Nov. }\end{array}$ & $\begin{array}{l}\text { I6 Feb. } \\
\text { I948 }\end{array}$ & $\begin{array}{l}\text { I Sept. to } \\
\text { I4 Oct. }\end{array}$ & 2 I Dec. & $\begin{array}{l}12 \text { Oct. to } \\
27 \text { Oct. }\end{array}$ & 27 Oct. & $\begin{array}{l}22 \text { Oct. } \\
\text { to } 4 \text { Nov. }\end{array}$ & 4 Nov. \\
\hline Plymouth, Rum Bay & - & - & 一 & - & $\begin{array}{l}\text { I Sept. to } \\
\text { I4 Oct. }\end{array}$ & 23 Nov. & $\begin{array}{l}\text { I2 Oct. to } \\
4 \text { Nov. }\end{array}$ & 4 Nov. & - & - \\
\hline
\end{tabular}


I952, but elsewhere occurred up to a month earlier. Practically all stations reached peak spawning (over $90 \%$ ), in spite of this, some time in November.

Details of spawning can only be inferred from the samples, since actual 'running' specimens were rarely seen, although a slow release of eggs was obtained from later spawning stages in the laboratory. The first indication of spawning in the samples was usually a fairly sudden decline in gonad size, but after this, liberation of eggs and sperm must have continued slowly, for 2-4 weeks passed before the first fully spent (stage I) individuals appeared. Thus the rapid swing from the developing to the spawning condition which frequently occurred must be distinguished from the swift and complete voiding of gametes that can take place in some other organisms. The spawning of the population as a whole was also slow compared with some other organisms, and it was sometimes 6 months or more (Io months in the more northern localities) after the start of spawning before all specimens had passed into the resting or developing phases.

Although the peak of spawning occurred from October to March at all localities, and thus Patella vulgata is to be regarded as a winter spawning species in Britain, the tables and figures show that some spawning can occur from September to the following June. In the more northerly stations, in certain years, the spawning season may be very extended. In June I949, specimens of $P$. vulgata containing ripe genital products were still fairly plentiful at St Andrews (over $40 \%$ spawning stages in sample) and an artificial fertilization was made from which larvae were reared through metamorphosis (Dodd, I956). It must therefore be stressed that gonad examination over a period of more than I year is necessary before any decision can be made about the breeding periods of limpets and related gastropods: little reliance can be placed on a few isolated samples. Records of the occurrence of the larvae in the plankton, unless made at frequent intervals over a long period, may also have little value.

\section{SPAWNING STIMULI}

The rapidity of the onset of spawning is to some extent a gauge of the strength of the supposed stimulus that induces spawning. For example, in 1946 at Trevone, in 1947 at Millport, Port St Mary, and Trevone, in I948 at Millport and Port St Mary, and in I949 at Plymouth over 90\% of the samples were spawning or spent within a month after the first spawning specimens were found. Presumably on these occasions the stimulus to spawn was stronger than at other times. The stimulus can hardly be internal, since in some years the whole population at different localities was involved within a few days, while in other years there were differences between almost adjacent populations (e.g. compare Plymouth breakwater and Plymouth, Rum Bay, in 1948, and the east and west coasts of the Isle of Man in I947; Table III). At the same time the onset of spawning can hardly be due to some climatic or hydrographic factor 
such as temperature or the nature of the water masses, since spawning may start simultaneously in different areas. The spawning stimulus does in fact appear to be capable of over-riding the breeding-cycle; for example, at Trevone in 1948, it appears to have arrived relatively early, for spawning began while the mean state of development of the gonad was low. Quite frequently spawning occurs while this index is at III or IV.

These differences appear to preclude any relation between spawning and the phases of the moon such as may occur in other organisms (e.g. Ostrea, Orton, 1926, I927; Arenicola, Newell, I948). Samples were not taken at sufficiently close intervals for possible lunar periodicity in spawning to be shown with any accuracy, except for the series from Port St Mary and Trevone in I947. These particular samples show little lunar influence; the main spawning stimulus seems to have arrived between 22 and 25 October, some 12 days behind the full moon, and during a period of neap tides. Samples taken at less frequent intervals in other years, e.g. at Plymouth in 1949 and at Port St Mary in I948, also suggest that any correlation between the moon and spawning lay with a period of neap tides; but the extent of such correlation was slight.

There is much better indication of a relation between wave-action or onshore winds and the start of spawning. For example in 1947 spawning began at Trevone between 17 September and II October, and continued very weakly (not more than $7 \%$ spawners) up to $2 \mathrm{I}$ October. During this period some rough seas may have been experienced since on a few days winds at St Eval, North Cornwall, (Air Ministry, 1947) reached 2I knots between south-west and north. A very strong stimulus to spawning appears to have been in operation between 2 I October and 4 November, by which date over $80 \%$ of the samples were in the spawned condition. This strong stimulus coincided with the occurrence on six of the days of winds of 21 knots and over between south and west at St Eval, and on four of these days the wind reached 30 knots or over. In the same year at Port St Mary the initial stimulus also appears to have been weak, and may have been associated with winds of up to 2 I knots (once 27) recorded at the Pt. of Ayre, I.O.M. (Air Ministry, I947) from south-east to west between 6 and 22 October. The major spawning stimulus seems to have arrived between 22 and 25 October, when the wind (recorded at the Pt. of Ayre) sometimes reached 2I knots from the southeast. This is the critical wind sector for the Port St Mary collecting station, and causes maximum wave action there.

At the other localities in I947, the onset of spawning was much more gradual.

An extremely rapid swing-over to the spawning condition occurred at Port St Mary in 1948 between 24 September and I3 October, a period of almost continuously high winds and rough seas around the Isle of Man. Thus the winds recorded at the Pt. of Ayre (Air Ministry, I948) reached 2I knots between south-east and west on 8 days, and over 30 knots on 3 days, while from personal observations the seas at Port St Mary were very rough. 
At the other localities conditions were much calmer in 1948. At Plymouth the wind rarely exceeded I6 knots during September and October, and it is therefore interesting that this was a year in which spawning progressed very slowly there.

In I949 the change to the spawning condition was more rapid at Trevone and Plymouth than at the other stations. At St Andrews and Port St Mary the initial spawning seems to have coincided with the occurrence of winds of up to 2I knots about 2I-22 September, from the north-east at Leuchars, near St Andrews (Air Ministry, I949) and from the south-east at Ronaldsway Airport, near Port St Mary. There was little wind at Plymouth during this period. The maximum change to the spawning condition at Plymouth and Trevone took place from I2 October to the end of the month, and seems to have coincided with winds of $2 \mathrm{I}-30$ knots from the south and west between I5 and 22 October, and similar winds from south through west to north between 22 and 26 October, at Plymouth and St Eval (Air Ministry, I949).

The change to the spawning condition was even more rapid at St Andrews in 1952 , between $2 \mathrm{I}$ and 27 September; the whole population was spent by 4 October. Winds of over 20 knots, sometimes 30 knots, were recorded practically every day during this period from directions between west and north at Leuchars (Air Ministry, I952), and rough seas must have been fairly continuous. At Port St Mary spawning appears to have started about the same period, when rough seas were observed practically continuously from 23 to 28 September, and the winds at Ronaldsway Airport exceeded 20 knots, and sometimes reached 30 knots, from directions between south and north-west (Air Ministry, I952). At Plymouth spawning was later. Rough seas were observed on only 3 isolated days in September, and spawning seems to have corresponded with rough seas on 25 to 27 October, and winds of 22-35 knots from south to west from 25 to 29 October.

Thus in 1947-49 and 1952 the initiation of spawning and periods of rapid changeover to the spawning condition coincided with periods of strong onshore winds and rough onshore seas. On some occasions also, as mentioned above, the greatest changeover to the spawning condition coincided with neap tides. If wave-action or onshore winds are major factors stimulating spawning, their effect would be enhanced during neap tides, when the smaller tidal range and slower movement would prolong their influence on the limpet habitat.

If the phenomena of wave-action or onshore winds and spawning are related, it becomes important to consider how the relationship is mediated. The direct effect of mechanical shock is an obvious factor to consider (cf. Chipperfield, 1953). It might either trigger spawning in the majority of individuals in a population, or else induce it in the ripest members which in turn might stimulate the remainder through a chemical effect of the gametes or other substances released on spawning. It may also be that some chemical or biological factor which induces spawning is brought inshore by turbulence. These and other possibilities have been investigated by an extensive series of laboratory experi- 
ments which have failed to show effects of the kind postulated. However, it must be admitted that experiments of this sort are hard to design satisfactorily and extremely difficult to carry out in the laboratory and the negative results must be interpreted accordingly.

The problem of spawning stimuli has been studied in detail in the other species of Patella, and will be discussed further in a later paper.

\section{COMPARISON WITH OTHER ANIMALS}

The breeding cycle which we have described for Patella vulgata contrasts markedly with the cycle in the lamellibranch molluscs, the reproductive processes of which proceed more rapidly. For example, in Ostrea (Orton, I926, I927, I936), and in Pecten (Mason ${ }^{1}$ ), which breed during the summer in Britain, the gonad empties rapidly, and sometimes two batches of gametes can be matured before the autumn. In the former species, although only one batch of eggs is produced by a female, a high proportion of the females switch rapidly to the male phase and start sperm production immediately after spawning. Even in intertidal Mytilus (Chipperfield, I953) the act of spawning, both of individuals and of the population as a whole, is much more rapid than in Patella vulgata. The same applies to most fish with planktonic larvae (e.g. Clupea, Orton, I916), though in some (e.g. Gadus merlangus, Bowers, 1954), the spawning period of the population may be as extensive as that of Patella.

The resting period in $P$. vulgata seems unduly extended when compared with the duration of the similar stage found in some lamellibranchs (Chipperfield, I953) and fishes (Orton \& Jones, I940; Jones, I940). In fact it may be said that the predominant feature of the breeding of $P$. vulgata is the slow progression of the cycle. Since it is possible that this slow progression is connected with winter breeding, it is instructive to compare Patella with another intertidal animal which starts to spawn at about the same time of the year, the lugworm Arenicola marina. Although the period of development of the eggs and sperm, June to October or November (Newell, 1948; Southward, I953), is similar to that of Patella vulgata, the gametes are voided much more rapidly in Arenicola: this means that the resting period is correspondingly longer than in Patella vulgata. It may be that animals with a northern distribution, which spawn in late autumn or winter, are characterized by a long resting period.

Some investigations which are being made by one of us (A.J.S.) on the breeding of certain common intertidal top-shells indicate that Osilinus lineatus and Gibbula umbilicalis have a breeding cycle very similar to that of Patella vulgata, although the resting phase may be shorter. As these animals occupy very similar habitats, and have habits similar to those of limpets, it seems

${ }^{1} \mathrm{~J}$. Mason. 'Investigations on the scallop (Pecten maximus L.) in Manx waters.' Univ. Liverpool, Ph.D. Thesis, 1953. 
possible that the slowness of the breeding cycle, and in particular the slow progression of spawning, is coupled with the mode of life. If the rate of growth is any guide (Fischer-Piette, I94I) the vital activities of limpets, especially at the higher levels on the shore, proceed at a very slow rate: one might therefore expect that the breeding cycle in such animals would progress slowly.

The field work and collection of samples were supported by grants from the Royal Society. Further assistance was provided by the University of Liverpool, the University of St Andrews and the D.S.I.R. We are also indebted to the Carnegie Trust for the Universities of Scotland for a generous grant towards the cost of publishing Pl. I.

Many individual workers assisted in this study, both in the field and in the laboratory, among whom we should like to mention: Mrs Orton, Dr M. H. I. Dodd, Dr M. Lang, Miss M. Craig, Dr N. S. Jones, Dr K. Munday; and Messrs J. R. Bruce, W. Crewe, M. D. Pittam, D. W. Tucker, C. Grainge, A. Patrick, and the late Mr P. Bond. Unfortunately, we have no means of ensuring that this is a complete record of those to whom thanks are due and we apologize for any omissions.

\section{SUMMARY}

Observations have been made on the breeding of Patella vulgata, by examination of regular samples from six localities in Britain over a period of 5 years.

The gonad stages were examined and grouped according to an arbitrary scheme, the advantages of which are discussed. Criteria are given by which the arbitrary stages can be distinguished, and their anatomy and histology described.

$P$. vulgata is shown to be a winter breeder in Britain. The gonad develops from June to September, and the peak of spawning occurs between October and December. Subsidiary spawning may take place at any time between September and June. From January to June the gonads pass into a resting phase. The length of the resting phase, and the proportion of individuals resting at any one time may be related to the temperature of the locality.

The main period of spawning varies from year to year and from place to place. It is not obviously related to temperature, tides, nor to the phases of the moon. The only factors with which spawning appears so far to be correlated are rough seas and onshore winds. Spawning may therefore be initiated either by physical shock, or some factor brought inshore from deeper water, but all attempts to investigate the phenomenon experimentally have failed.

In comparison with other molluscs, $P$. vulgata has a much longer resting phase, but it seems possible that this is characteristic of some winter-breeding intertidal animals. 


\section{REFERENCES}

AIR Ministry, 1947-52. The Daily Weather Report of the Meteorological Office. London.

Bowers, A. B., I954. Breeding and growth of whiting (Gadus merlangus L.) in Isle of Man waters. F. Mar. biol. Ass. U.K., Vol. 33, pp. 97-I22.

ChIPperfield, P. N. J., I953. Observations on the breeding and settlement of Mytilus edulis (L.) in British waters. F. Mar. biol. Ass. U.K., Vol. 32, pp. 449-76.

DoDD, J. M., I956. Artificial fertilization, larval development and metamorphosis in Patella vulgata L. and Patella coerulea L. Pubbl. Staz. Zool. Napoli (in press).

EsLICK, A., I940. An ecological study of Patella at Port St Mary, Isle of Man. Proc. Linn. Soc. Lond., Sess. I52, pp. 45-58.

FisCher-PietTE, E., I94I. Croissance, taille maxima, et longévité possible de quelques animaux intercotideaux en fonction du milieu. Ann. Inst. océanogr. Monaco, Vol. 2I, I-28.

Goodwin, T. W., 1950. Carotenoid distribution in the gonads of the limpets Patella vulgata and Patella depressa. Biochem. F., Vol. 47, pp. 249-5I.

GoodwIn, T. W. \& TAHA, M. M., I950. The carotenoids of the gonads of the limpets Patella vulgata and Patella depressa. Biochem. F., Vol. 47, pp. 244-9.

JONES, J. W., I940. Histological changes in the testis in the sexual cycle of male salmon parr (Salmo salar L. juv.). Proc. roy. Soc., B, Vol. I28, pp. 499-509.

Newell, G. E., 1948. A contribution to our knowledge of the life-history of Arenicola marina L. F. Mar. biol. Ass. U.K., Vol. 27, pp. 554-79.

ORTON, J. H., I9I6. An account of researches on races of herrings carried out by the Marine Biological Association at Plymouth, I9I4-15. F. Mar. biol. Ass. U.K., Vol. II, pp. 7I-I2I.

- 1920. Sex-phenomena in the common limpet (Patella vulgata). Nature, Lond., Vol. 104, p. 373.

- 1926. On lunar periodicity in spawning of normally grown Falmouth oysters (O. edulis) in 1925. F. Mar. biol. Ass. U.K., Vol. I4, pp. 199-225.

- 1927. Observations on sex-change in the European oyster (O. edulis). Part I. The change from female to male. F. Mar. biol. Ass. U.K., Vol. I4, pp. 967-I055.

- 1928. Observations on Patella vulgata, Part I. Sex-phenomena, breeding and shell growth. F. Mar. biol. Ass. U.K., Vol. 15, pp. 851-62.

- 1936. Observations and experiments on sex-change in the European oyster (O. edulis). Part V. A simultaneous study of spawning in two distinct localities. Mem. Mus. Hist. nat. Belg., Sér. 2, Fasc. 3, pp. 997-1056.

1946. Biology of Patella in Great Britain. Nature, Lond., Vol. 158, p. 173.

Orton, J. H. \& Jones, J. W., I940. The paedogenetic male cycle in Salmo salar L. Proc. roy. Soc. B, Vol. I28, pp. 485-99.

Southward, A. J., I953. The fauna of some sandy and muddy beaches in the south of the Isle of Man. Proc. Lpool biol. Soc., Vol. 59, pp. 5I-7I.

SOUTHWARD, A. J. \& ORTON, J. H., I954. The effects of wave action on the distribution and numbers of the commoner animals living on the Plymouth breakwater. F. Mar. biol. Ass. U.K., Vol. 33, pp. I-I9. 


\section{APPENDIX}

Table IV. Distribution of Gonad Stages in Samples of Patella VULGATA FROM ABERDEEN

\begin{tabular}{|c|c|c|c|c|c|c|c|c|c|c|c|c|c|c|c|c|c|c|c|c|}
\hline \multirow[b]{3}{*}{ Date } & \multirow{3}{*}{$\begin{array}{l}\text { No. in } \\
\text { sample }\end{array}$} & & \multicolumn{7}{|c|}{ Male } & \multicolumn{3}{|c|}{ Neuter } & \multicolumn{8}{|c|}{ Female } \\
\hline & & & \multicolumn{4}{|c|}{ Developing } & \multicolumn{4}{|c|}{ Spawning } & & & \multicolumn{4}{|c|}{ Developing } & \multicolumn{4}{|c|}{ Spawning } \\
\hline & & I & II & III & IV & V & IV & III & II & I & & I & II & III & IV & $\mathrm{V}$ & IV & III & II & I \\
\hline I947 & & & & & & & & & & & & & & & & & & & & \\
\hline . & I I 6 & - & - & - & - & - & - & - & 2 & 23 & 63 & - & - & - & - & - & - & - & - & 28 \\
\hline ay & 97 & - & - & - & - & - & - & - & - & I5 & 6 & - & - & - & - & - & - & - & - & 20 \\
\hline ly & 96 & Io & 2 & I & - & - & - & - & - & - & 68 & I & - & - & - & - & - & - & - & I4 \\
\hline ug. & II 3 & 2 & 30 & I7 & 4 & - & - & - & - & - & I & 26 & $3 I$ & 2 & - & - & - & - & - & - \\
\hline & 98 & I & 6 & I9 & 7 & - & - & - & - & - & 一 & 7 & 20 & $3 I$ & 7 & - & - & - & - & - \\
\hline & I 23 & 一 & 3 & IO & 25 & I3 & - & I & - & - & I & - & 5 & 13 & 32 & 20 & - & - & - & - \\
\hline t. & II 8 & 一 & - & 6 & $3 I$ & I3 & I & 7 & - & - & - & - & - & 8 & 27 & I3 & - & 9 & 3 & - \\
\hline ov. & I34 & 一 & 2 & - & 4 & I & 8 & 26 & 26 & - & - & - & 3 & 4 & I8 & 7 & - & 3 & 22 & IO \\
\hline bv. & 103 & 一 & 一 & I 2 & 22 & IO & 3 & II & 5 & - & - & - & - & - & I7 & IO & I & 8 & 2 & 2 \\
\hline v. & I IO & - & - & 4 & - & I2 & 9 & IO & 2 & 2 & - & - & 2 & 4 & IO & 26 & IO & IO & 8 & I \\
\hline & IO4 & - & - & I & 3 & I5 & 5 & 7 & 4 & I & - & - & - & I & I & 33 & IO & I3 & 8 & 2 \\
\hline & I2I & - & - & 2 & I & 5 & I8 & $2 \mathrm{I}$ & 2 & - & I & - & - & - & 3 & 25 & II & 24 & 7 & 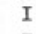 \\
\hline & IOI & - & - & 2 & - & 4 & 7 & 22 & 5 & - & - & - & I & - & 5 & I6 & I4 & $\mathrm{I} 2$ & I2 & \\
\hline & IO4 & - & I & 5 & 2 & 5 & 5 & 34 & 5 & - & - & - & I & 2 & 5 & 8 & I2 & 9 & 9 & I \\
\hline
\end{tabular}

I948

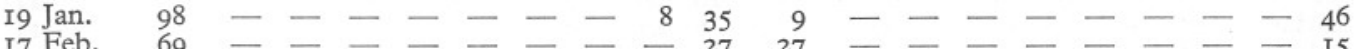

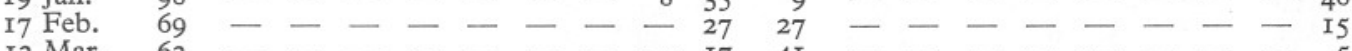

I3 Mar. 63 - - - - - - - I7 $4 \mathrm{I}--\ldots-5$

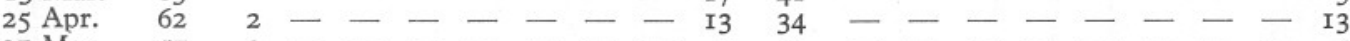

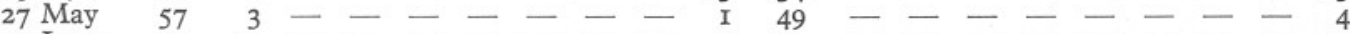

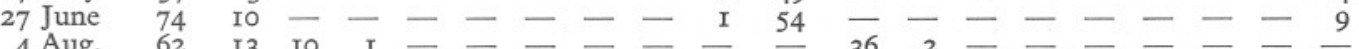

4 Aug. 62 I3 10 I 6 - - - - - 36 2 - - - -

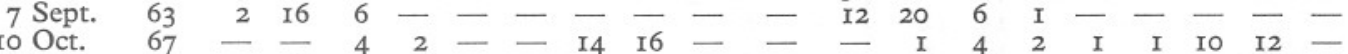

I8 Oct. $\quad 56-9992-4 \begin{aligned} & 4 \\ & \text { I }\end{aligned}$

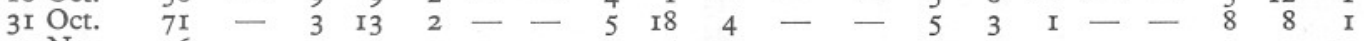

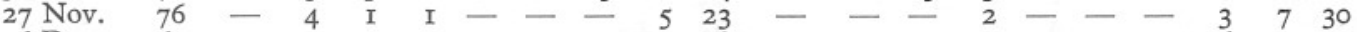

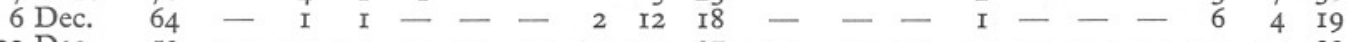

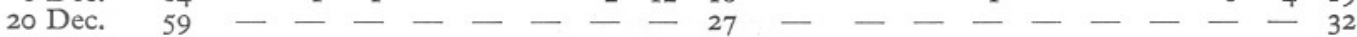

1949

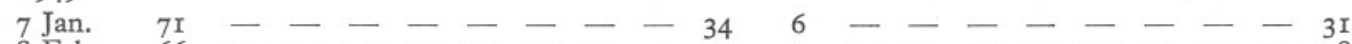

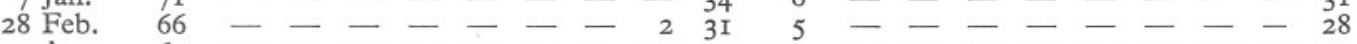

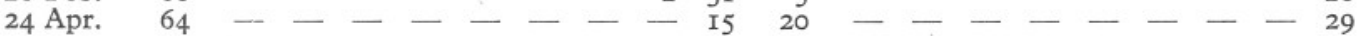


Table V. Distribution of Gonad Stages in Samples of Patella VULGATA FROM ST ANDREWS

\begin{tabular}{|c|c|c|c|c|c|c|c|c|c|c|c|c|c|c|c|c|c|c|c|c|}
\hline \multirow[b]{3}{*}{ Date } & \multirow{3}{*}{$\begin{array}{l}\text { No. in } \\
\text { sample }\end{array}$} & \multicolumn{8}{|c|}{ Male } & \multicolumn{3}{|c|}{ Neuter } & \multicolumn{8}{|c|}{ Female } \\
\hline & & \multicolumn{4}{|c|}{ Developing } & & \multicolumn{4}{|c|}{ Spawning } & & & \multicolumn{4}{|c|}{ Developing } & \multicolumn{4}{|c|}{ Spawning } \\
\hline & & I & II & III & IV & V & IV & III & II & I & & I & II & III & IV & V & IV & III & II & I \\
\hline \multicolumn{21}{|l|}{ I947 } \\
\hline 3 Nov. & 105 & - & I & 3 & I7 & ro & 4 & 6 & 2 & - & - & - & 3 & 5 & 29 & 20 & I & I & 3 & - \\
\hline $5 \mathrm{~N}$ & I 26 & - & - & - & - & $2^{\star}$ & 6 & II & 24 & I7 & - & - & I & I & 4 & 7 & 3 & 4 & 9 & 37 \\
\hline I8 Dec. & 94 & - & I & - & - & - & - & 8 & 16 & 7 & - & - & - & I & I & - & 3 & 13 & 25 & 19 \\
\hline \multicolumn{21}{|l|}{ I 948} \\
\hline I6 Ja & 88 & - & I & - & - & - & - & - & 7 & 31 & 3 & - & - & - & - & - & - & I & - & 45 \\
\hline II F & 109 & - & - & - & - & - & - & - & - & $4 \mathrm{I}$ & 24 & - & - & - & - & - & - & - & - & 44 \\
\hline 20 Aug. & 105 & I & I8 & 38 & 2 & I & - & I & 2 & - & - & 2 & 29 & Io & I & - & - & - & - & \\
\hline I7 Sept. & 122 & I5 & 40 & I4 & 8 & - & - & - & - & - & - & - & 8 & 32 & 5 & - & - & - & - & - \\
\hline 8 Oct. & III & - & $I$ & 26 & 22 & 2 & - & I8 & 4 & - & - & - & - & 2 & I6 & 7 & 4 & 9 & - & - \\
\hline 30 & I 20 & - & 2 & 30 & I2 & - & - & 24 & I2 & - & - & - & I & II & $\mathrm{I} 4$ & 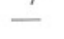 & 4 & 8 & 2 & - \\
\hline 20 Oct. & 49 & - & - & 8 & 8 & - & - & 19 & - & - & - & - & - & 2 & 5 & - & - & 5 & 2 & - \\
\hline 29 Oct. & 90 & - & - & I8 & 20 & 2 & - & 13 & - & - & - & $\cdot-$ & - & 4 & IO & 8 & IO & 5 & - & - \\
\hline 2 Nov. & I 28 & - & - & 4 & - & - & - & 3 & 32 & 40 & - & - & - & - & - & - & - & 2 & 5 & 42 \\
\hline 23 Nov. & 65 & - & - & - & - & - & - & 5 & I8 & I3 & - & - & - & - & - & - & - & - & 3 & 26 \\
\hline 24 Dec. & 57 & - & - & - & - & - & - & - & 6 & 30 & - & - & - & - & - & - & - & - & - & $2 \mathrm{I}$ \\
\hline \multicolumn{21}{|l|}{ I949 } \\
\hline I4 Jan. & 53 & - & - & - & - & - & - & - & 6 & 27 & - & - & - & - & - & - & - & - & - & 20 \\
\hline $4 \mathrm{Fe}$ & $6 \varepsilon$ & - & - & I & - & - & - & - & I0 & 29 & 2 & - & - & - & - & - & - & - & 2 & 24 \\
\hline $4 \mathrm{Mz}$ & 6 & - & - & - & - & - & - & - & 6 & $4 \mathrm{I}$ & 2 & - & - & - & - & - & - & - & - & 16 \\
\hline $6 \mathrm{Ap}$ & 91 & 5 & 6 & - & - & - & - & - & - & 49 & 5 & 2 & I & - & - & - & - & - & - & 23 \\
\hline $26 \mathrm{Ap}$ & 100 & & 6 & I & - & - & - & - & 6 & 20 & 17 & I & 5 & 3 & I & - & - & - & & 36 \\
\hline $27 \mathrm{M}$ & 57 & 18 & 4 & - & - & - & - & - & - & II & 8 & - & I & I & - & - & - & - & - & I4 \\
\hline $24 \mathrm{Ju}$ & 55 & I2 & 5 & - & - & - & - & - & - & I3 & I4 & 3 & - & - & - & - & - & - & - & 8 \\
\hline 0 & 56 & IO & 9 & I & - & - & - & - & I & 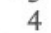 & 3 & 17 & 9 & - & - & - & - & - & - & 2 \\
\hline$A_{2}$ & 69 & 2 & 12 & I2 & - & I & - & - & 2 & & 5 & 6 & 20 & II & I & - & - & - & 2 & 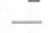 \\
\hline c & 60 & & I & I5 & 13 & 3 & - & I & 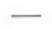 & - & - & 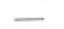 & I & I5 & 7 & 3 & - & I & & - \\
\hline 22 Sept. & 58 & - & 7 & 19 & 8 & - & - & - & - & - & - & - & 6 & 9 & 7 & 2 & - & - & - & - \\
\hline $30 \mathrm{Se}$ & 62 & - & 9 & 6 & - & 2 & - & - & I3 & - & - & - & 2 & I & - & - & - & - & 26 & 3 \\
\hline $5 \mathrm{O}$ & $6 \mathrm{I}$ & - & 2 & 3 & 3 & I & - & - & 24 & - & - & - & 9 & - & 2 & - & - & 4 & 13 & J \\
\hline I9 Nov. & $3 \mathrm{I}$ & - & 4 & - & & - & - & - & I2 & 2 & - & - & - & - & - & - & - & - & 6 & 7 \\
\hline
\end{tabular}


Table Vi. Distribution of Gonad Stages in Samples of Patella VULGATA FROM MILLPORT

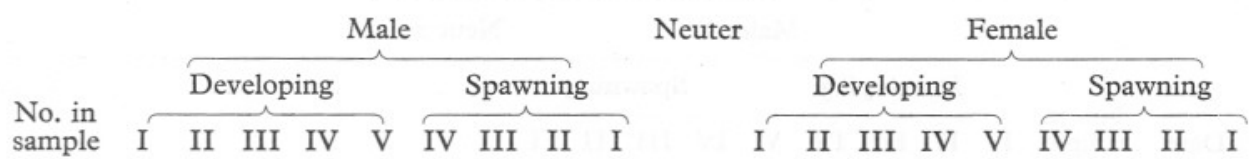

Date sample I II III IV V IV III II I

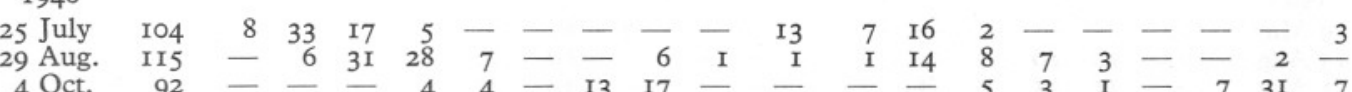

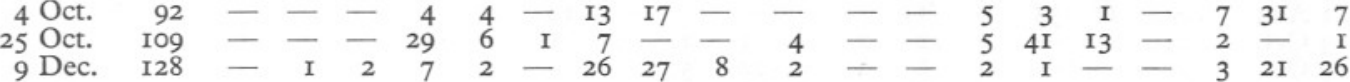

I947

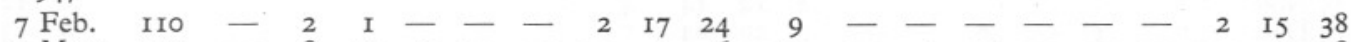

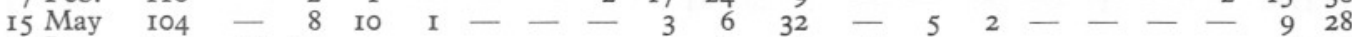

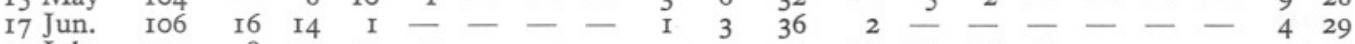

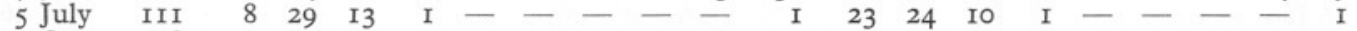

$\begin{array}{lrllllllllllllllllll}\text { I Oct. } & 98 & \text { I } & 25 & \text { I } & - & - & - & - & - & \text { I } & - & \text { I } & \text { I9 } & 33 & \text { I } & - & - & - & -\end{array}$

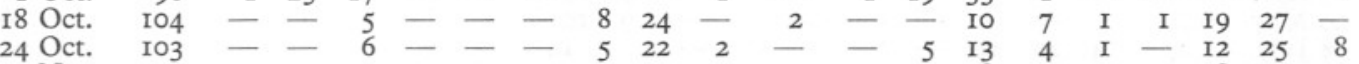

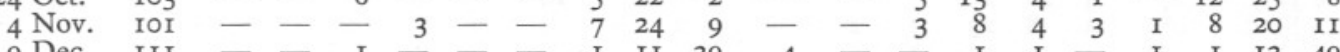

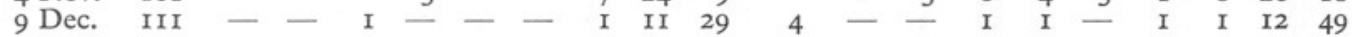

I948

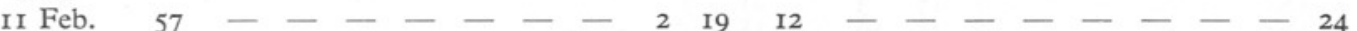

I Mar. 54 - - - - - - - - I5 I8 - - I - - - - - 20

22 Apr. $6 \mathrm{I}$ I $---6-645-6-6-6$

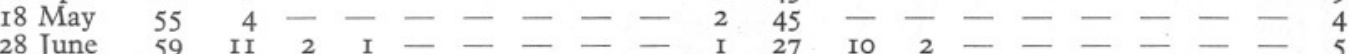

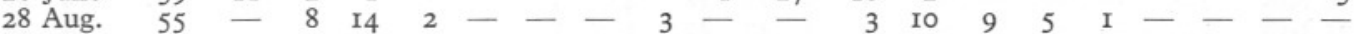

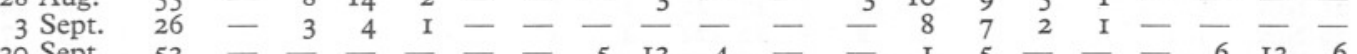

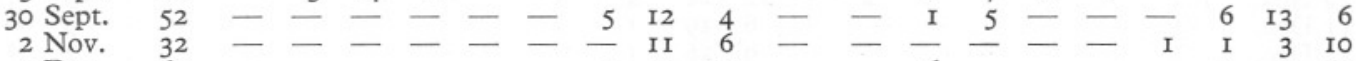

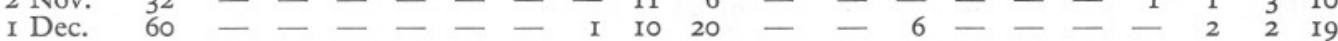

I949

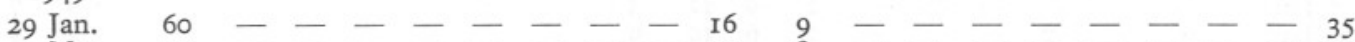

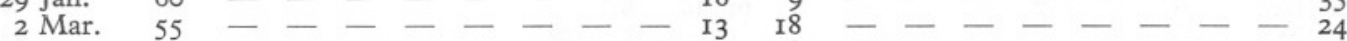

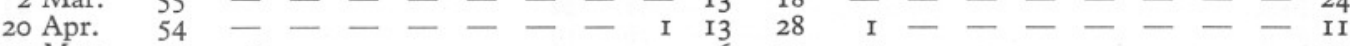

27 May $51 \quad 7-6-6-622$ I $-6-6-6-15$

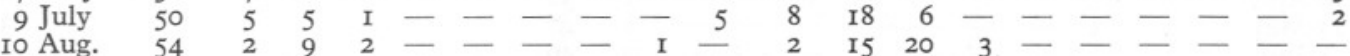

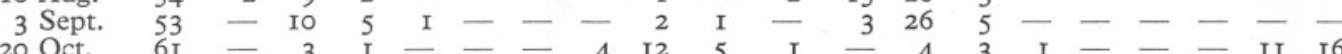

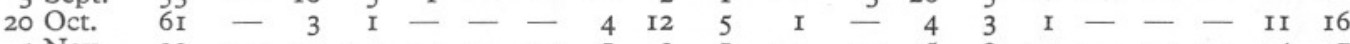

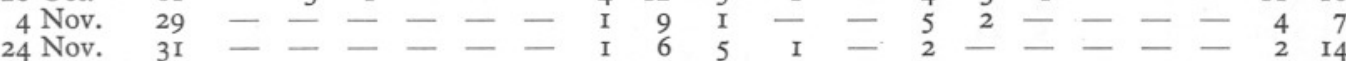




\section{Table VII. Distribution of Gonad Stages in Samples of Patella vulgata from Kallow Point, Port St Mary, Isle of Man}

\begin{tabular}{|c|c|c|c|c|c|c|c|c|c|c|c|c|c|c|c|c|c|c|c|c|}
\hline \multirow[b]{3}{*}{ Date } & \multirow{3}{*}{$\begin{array}{l}\text { No. in } \\
\text { sample }\end{array}$} & & \multicolumn{7}{|c|}{ Male } & \multicolumn{3}{|c|}{ Neuter } & \multicolumn{8}{|c|}{ Female } \\
\hline & & & \multicolumn{4}{|c|}{ Developing } & \multicolumn{4}{|c|}{ Spawning } & & & \multicolumn{4}{|c|}{ Developing } & \multicolumn{4}{|c|}{ Spawning } \\
\hline & & I & II & III & IV & V & IV & III & II & I & & $\mathrm{I}^{\prime}$ & II & III & IV & V & IV & III & II & \\
\hline 9 May & 102 & - & - & - & - & - & - & - & - & 7 & $8 I$ & - & - & - & - & - & - & - & - & \\
\hline I5 Aug. & IOI & IO & ro & 2 & - & - & - & - & - & - & 6 & Io & 2 & - & - & - & - & - & - & \\
\hline 2 I Aug. & IOO & II & 35 & 8 & I & - & - & - & - & - & I4 & 27 & 4 & - & - & - & - & - & - & \\
\hline 3 Oct. & 44 & - & - & 2 & 12 & 2 & - & I & 2 & - & I & - & - & 2 & I8 & 3 & - & - & I & \\
\hline I7 Oct. & 95 & - & - & - & 6 & 2 & 9 & 22 & 5 & - & - & - & 2 & 7 & 4 & - & - & 28 & IO & \\
\hline I Nov. & 94 & - & - & 8 & 8 & - & 7 & 20 & 5 & - & I & - & - & I2 & Io & - & - & - & 20 & \\
\hline 25 Nov. & 100 & - & - & - & - & - & 4 & I4 & I4 & 4 & - & - & I & I & 5 & - & - & 9 & 36 & I2 \\
\hline I3 Dec. & II 7 & I & - & 6 & - & - & I & 29 & 64 & 5 & - & - & - & - & 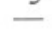 & - & - & 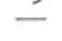 & 8 & \\
\hline I947 & & & & & & & & & & & & & & & & & & & & \\
\hline I6 Jan. & I06 & - & - & - & - & - & - & - & I6 & I & 53 & - & - & - & - & - & - & - & - & \\
\hline 9 Apr. & I 2 & - & - & - & - & - & - & - & - & 9 & 9 & - & - & - & - & - & - & - & - & \\
\hline 20 May & II 5 & - & - & - & - & - & - & - & - & 9 & IOI & - & - & - & - & - & - & - & - & \\
\hline 28 July & 97 & 4 & 20 & IO & - & - & - & - & - & - & I4 & 25 & 24 & - & - & - & - & - & - & \\
\hline 4 Sept. & I08 & 2 & 8 & 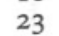 & 7 & 2 & - & - & I & - & I & II & 8 & I4 & - & - & - & - & I & \\
\hline 6 Oct. & I IO & - & I3 & 2 & I & - & - & - & - & - & - & I & 30 & 30 & 2 & - & - & - & - & \\
\hline 22 Oct. & I2I & - & - & II & 28 & 6 & - & 3 & - & - & I & - & - & 7 & 39 & 20 & - & 6 & - & \\
\hline 25 Oct. & 103 & - & - & 7 & I5 & 3 & - & $2 \mathrm{I}$ & 3 & - & - & - & I & I9 & 6 & 3 & - & 7 & 8 & \\
\hline 28 & II I & - & - & 3 & 5 & Io & I3 & I & I & - & 2 & - & - & 4 & 3 & 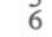 & 5 & 9 & 2 & \\
\hline 30 & 107 & - & - & $\pi$ & I2 & 3 & 5 & 2 & 6 & - & - & - & I & 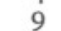 & & 7 & 4 & I8 & 7 & \\
\hline 3 Nov. & IIO & - & - & 2 & I2 & 3 & 6 & 3 & 5 & - & - & - & - & 2 & 11 & 4 & 7 & 4 & 2 & \\
\hline Io Nov. & 103 & - & - & - & 3 & 5 & 4 & 20 & I & 5 & - & - & - & 3 & 3 & 4 & 6 & 0 & 3 & \\
\hline I6. & 105 & - & - & - & - & I & 3 & 2 & & 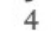 & I & - & - & 3 & 4 & 4 & - & $2 I$ & 4 & \\
\hline 25 & 105 & - & - & - & - & 4 & I & I & & & I & - & I & I & 7 & 6 & 6 & 8 & & \\
\hline lov. & IOI & - & - & - & I & 2 & 5 & 22 & & 4 & I & - & - & - & 2 & 3 & 4 & 13 & I5 & \\
\hline ec. & 55 & - & - & - & - & - & I & 6 & & I & I & - & - & 3 & - & - & I & 8 & 9 & \\
\hline 22 Dec. & 50 & - & - & - & - & - & - & 9 & I6 & I & - & - & - & - & 4 & 2 & 5 & 5 & 7 & \\
\hline I948 & & & & & & & & & & & & & & & & & & & & \\
\hline 7 Jan. & 53 & - & - & - & - & - & 2 & 9 & $\mathrm{I}_{2}$ & 3 & - & - & - & I & - & I & I & 8 & 9 & \\
\hline $28 \mathrm{~J}$ & 59 & - & 2 & - & - & - & 2 & 6 & I & 9 & - & - & - & 4 & 2 & - & I & 5 & 9 & \\
\hline I2 $\mathrm{F}$ & 56 & - & - & - & - & 一 & - & - & 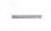 & $\mathrm{II}$ & 2 & 一 & - & - & - & - & - & - & - & \\
\hline $8 N$ & $5 \mathrm{I}$ & - & - & - & - & - & - & - & - & I6 & I9 & - & - & - & - & - & - & - & - & \\
\hline I6 & 5 & - & - & - & - & - & - & - & - & I & 5 & - & - & - & - & - & - & - & - & \\
\hline 251 & 53 & 2 & - & - & - & - & - & - & - & $I$ & 4 & - & - & - & - & - & - & - & - & \\
\hline $4 \mathrm{~J}$ & $5 \mathrm{I}$ & - & - & - & - & - & - & - & - & 1 & 49 & I & - & - & - & - & - & - & - & \\
\hline & 55 & I7 7 & 2 & - & - & - & - & - & - & - & 9 & 27 & - & - & - & - & - & - & - & \\
\hline 25 & 129 & - & 24 & 27 & II & - & - & - & - & - & - & 5 & 35 & 22 & 5 & - & - & - & - & \\
\hline 24 & 66 & - & 9 & 23 & 4 & - & - & - & - & - & - & - & I8 & I2 & - & - & - & - & - & \\
\hline I3 & 45 & - & - & - & - & - & - & I & 5 & 2 & 一 & - & I & - & - & - & - & I & I3 & \\
\hline 20 & 40 & - & - & - & - & - & - & - & 8 & $\mathrm{I} 2$ & - & - & 1 & - & - & - & - & - & 9 & \\
\hline 25 Nov. & 44 & - & - & - & - & - & - & - & I & I6 & - & - & - & - & - & - & - & - & - & \\
\hline & & & & & & & & & & & & & & & & & & & & \\
\hline & 48 & - & - & - & - & - & - & - & I & 20 & 5 & - & - & - & - & - & - & - & I & \\
\hline & & - & - & - & - & - & - & - & - & 3 & 4 & I & - & - & - & - & - & - & - & \\
\hline 25 & & I0 & - & - & - & - & - & - & - & - & 22 & 2 & - & - & - & - & - & - & - & \\
\hline II J & 45 & II & 2 & - & - & - & - & - & - & 3 & $2 I$ & 2 & - & - & - & - & - & - & - & \\
\hline & 49 & II & I4 & - & - & - & - & - & - & - & 4 & I4 & 6 & - & - & - & - & - & - & \\
\hline & 5 & - & I3 & 9 & - & - & - & - & - & - & - & I & 27 & 5 & - & - & - & - & - & \\
\hline & & - & 2 & - & - & - & - & - & I3 & IO & I & - & 5 & - & - & - & - & - & - & \\
\hline & 2 & - & 2 & - & - & - & - & - & 8 & - & - & - & - & - & - & - & - & - & 4 & \\
\hline 24 & 28 & - & - & - & - & - & - & - & 6 & 6 & - & - & - & - & - & - & - & - & 2 & \\
\hline
\end{tabular}


Table VIII. Distribution of Gonad Stages in Samples of Patella VULGATA FROM TREVONE

Male Neuter

Female

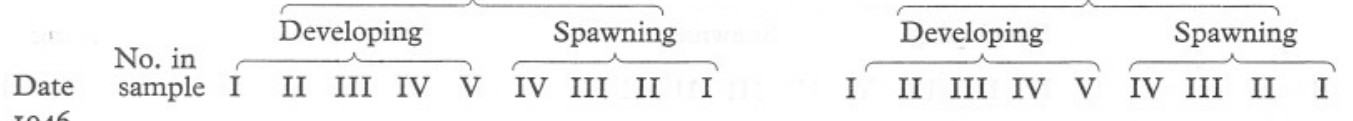

I946

I

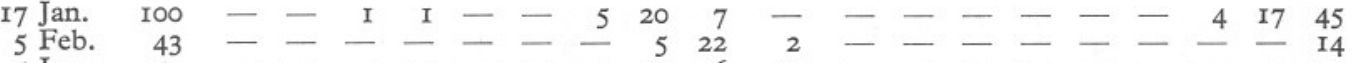

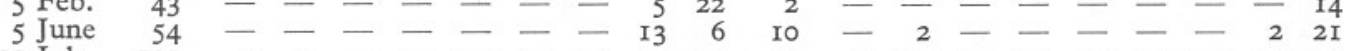

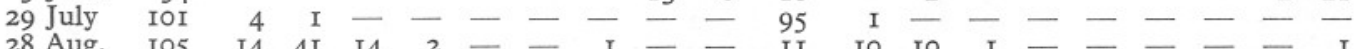

28 Aug. 105 I4 4 I I4 2 - - I - II I0 10 I ----- I

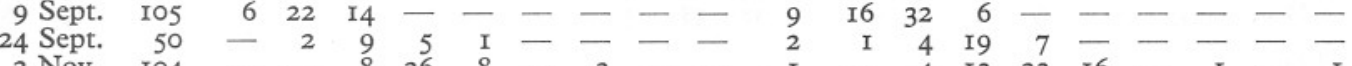

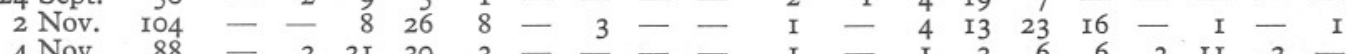

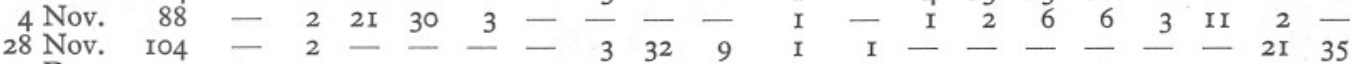

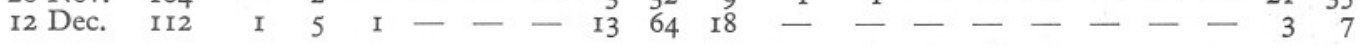

I947

3I Jan.

$102-\mathrm{I}-\mathrm{C}-\mathrm{C}-35026$

14 May

29 July

105

22 Aug. 104

I7 Sept. I03

II Oct.

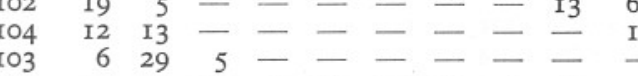

$2 \mathrm{I}$ Oct.

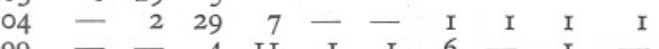

24 Oct $\quad$ - -49 II I I 6 -

4 Nov. IO

I4 Nov. IO

$-\quad-\quad \begin{array}{lllllrr}2 & \text { I4 } & 4 & - & \text { I2 } & 3 & -\end{array}$

Io Dec.

I 948

II Feb.

52

24 Apr. 55

I9 May 52

29 June

27 July

30 Aug. $\quad 54$

I3 Oct. 55

I4 Nov. 5

I Dec. 55

I949

31 Jan. 53

I4 Mar. $\quad 52$

27 May

II July

9 Aug.

IO Sept 5 I

I9 Oct.

4 Nov.

24 Nov.

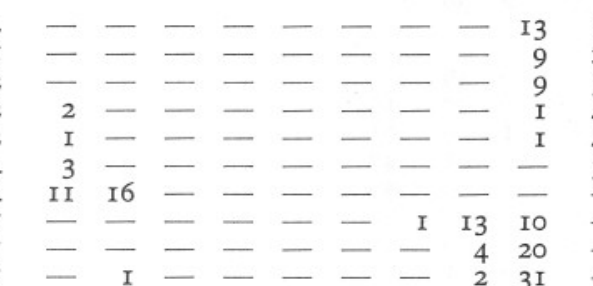

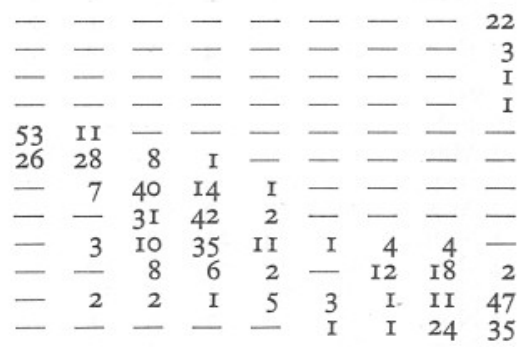

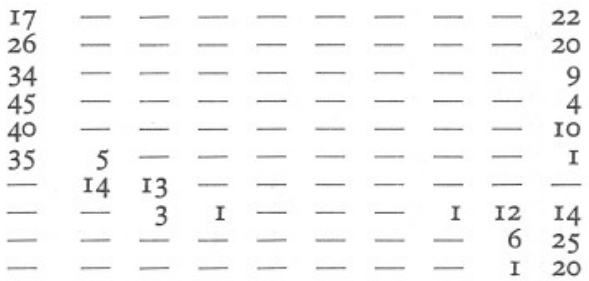

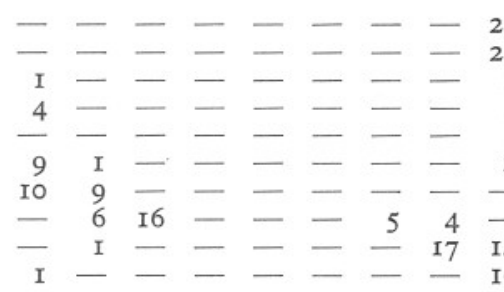

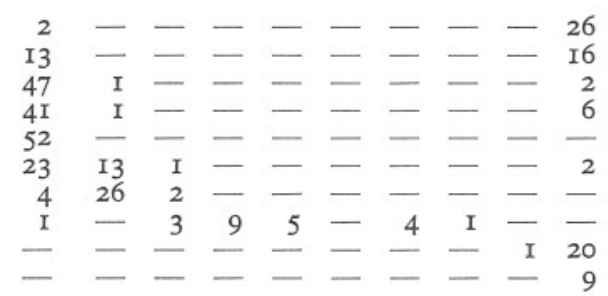


Table IX. Distribution of Gonad Stages in Samples of Patella VUlGata FROM Plymouth Breakwater

\begin{tabular}{|c|c|c|c|c|c|c|c|c|c|c|c|c|c|c|c|c|c|c|c|c|}
\hline \multirow[b]{3}{*}{ Date } & \multirow{3}{*}{$\begin{array}{l}\text { No. in } \\
\text { sample }\end{array}$} & & \multicolumn{7}{|c|}{ Male } & \multicolumn{3}{|c|}{ Neuter } & \multicolumn{8}{|c|}{ Female } \\
\hline & & & \multicolumn{4}{|c|}{ Developing } & \multicolumn{4}{|c|}{ Spawning } & & & \multicolumn{4}{|c|}{ Developing } & \multicolumn{4}{|c|}{ Spawning } \\
\hline & & I & II & III & IV & V & IV & III & $\mathrm{I}$ & I & & I & I & III & IV & V & $\mathrm{V}$ & III & II & \\
\hline I8 June & I4I & IO & 7 & 2 & - & - & - & - & - & I5 & $9 I$ & - & - & - & - & - & - & - & I & I \\
\hline $30 \mathrm{~J}$ & I37 & I & - & - & - & - & - & - & & - & & I & - & - & - & - & - & - & - & \\
\hline I & II 2 & - & - & 9 & 39 & 6 & - & 一 & - & 一 & . & - & 2 & I9 & $3 I$ & 6 & - & - & - & \\
\hline $28 \mathrm{C}$ & I 20 & - & - & 10 & $\mathrm{I}$ & 7 & - & I & 2 & - & - & - & I & 25 & 33 & I4 & - & 9 & 3 & \\
\hline $27 \mathrm{~N}$ & I34 & - & - & 3 & 4 & - & I & 24 & I9 & I & & - & I & 3 & I & - & 一 & 15 & 54 & \\
\hline Io Dec & I4 & - & 9 & 4 & 2 & - & - & 38 & 38 & 5 & 一 & - & I & - & - & - & I & 6 & 29 & \\
\hline I947 & & & & & & & & & & & & & & & & & & & & \\
\hline I7 Feb. & I 54 & - & I2 & 3 & - & - & - & - & $3 I$ & $3 I$ & 7 & - & - & - & - & - & - & I & 6 & \\
\hline 71 & $\mathrm{I}$ & - & - & - & - & 一 & - & - & - & 2 & 187 & - & - & - & - & - & - & - & - & \\
\hline I I J & 1 & 4 & I & - & 一 & - & - & - & - & - & II8 & - & - & - & - & - & - & - & - & . \\
\hline $6 c$ & I & - & I & 30 & 2 & I & - & 一 & - & - & 一 & - & 5 & 70 & I5 & 2 & - & - & 一 & \\
\hline 31 & $x$ & 一 & 2 & - & 6 & I & 2 & I7 & I & 2 & - & - & - & 6 & $\mathrm{I}$ & 6 & - & 9 & 3 & \\
\hline II Nov. & I0 & - & - & - & I & 2 & I & I5 & 1 & 2 & - & - & - & 4 & 8 & I7 & I & 13 & 23 & \\
\hline 4 Dec. & 100 & - & 4 & 2 & 3 & 7 & 2 & 9 & 4 & - & - & - & - & 2 & - & 33 & 2 & IO & 22 & \\
\hline I948 & & & & & & & & & & & & & & & & & & & & \\
\hline I6 Feb. & 50 & - & 一 & 一 & - & - & - & - & - & $2 I$ & & - & - & - & - & - & - & - & - & \\
\hline $2 I$ & I5 & - & - & - & - & - & - & - & - & 4 & 1 & - & - & - & - & - & - & - & - & \\
\hline $5 J$ & 61 & 5 & - & - & - & - & - & - & - & 3 & 37 & 2 & - & - & - & - & - & - & - & \\
\hline & 93 & 17 & 2 & - & - & - & - & - & - & - & & & $\pi$ & - & - & - & - & - & - & 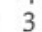 \\
\hline & 7 & 4 & $2 \mathrm{I}$ & 2 & - & - & - & - & - & - & - & 2 & 32 & - & - & - & - & - & - & \\
\hline I4 & 6 & - & - & 8 & Io & - & - & 3 & - & - & - & - & 2 & I5 & 8 & 2 & 4 & IO & - & \\
\hline & 3 & - & I & 5 & - & - & - & - & 7 & - & - & $T$ & 4 & & 3 & I & - & 2 & 3 & \\
\hline & 100 & - & 2 & 3 & $T$ & - & - & 5 & 2 & 7 & - & -- & 5 & & 7 & - & - & IO & 5 & I \\
\hline 30 & 99 & - & - & 4 & - & - & - & 6 & $2 \mathrm{I}$ & 3 & - & - & 8 & IO & 4 & I & I & I3 & I5 & 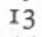 \\
\hline $2 \mathrm{II}$ & & - & - & - & - & - & - & - & 2 & 38 & - & - & - & - & - & - & - & - & - & \\
\hline & & & & & & & & & & & & & & & & & & & & \\
\hline I & 7 & - & - & - & - & - & - & - & - & 29 & - & - & - & - & - & - & - & - & - & 4 \\
\hline & & - & - & - & - & - & - & - & - & 27 & I6 & - & - & - & - & - & - & - & - & 3 \\
\hline 31 & 8 & 2 & - & - & - & - & - & - & I & 6 & $6 \mathrm{r}$ & 4 & 3 & - & - & - & - & - & - & \\
\hline $28 \mathrm{~J}$ & 50 & I & - & - & 一 & - & - & - & - & I & 47 & 1 & - & - & - & - & - & - & - & \\
\hline & & 4 & 3 & - & - & - & - & - & - & - & 30 & $\mathrm{I} 2$ & - & - & - & - & - & - & - & 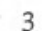 \\
\hline & 66 & 9 & I8 & - & - & - & - & - & - & - & - & 25 & I3 & - & - & - & - & - & - & \\
\hline & 56 & - & 4 & I4 & 2 & - & - & - & - & - & - & - & II & 24 & I & - & - & - & - & \\
\hline 27 & 82 & - & I & - & - & - & - & - & 29 & I & - & - & - & - & - & - & - & - & I5 & \\
\hline 3 & 40 & 2 & - & - & - & - & - & - & 6 & I0 & - & - & - & - & - & - & - & - & I & \\
\hline
\end{tabular}

